\title{
RECONNAISSANCE OF HYDROLOGY, LAND USE, GROUND-WATER CHEMISTRY, AND EFFECTS OF LAND USE ON GROUND-WATER CHEMISTRY IN THE ALBUQUERQUE-BELEN BASIN, NEW MEXICO
}

By Scott K. Anderholm

U.S. GEOLOGICAL SURVEY

Water-Resources Investigations Report 86-4174

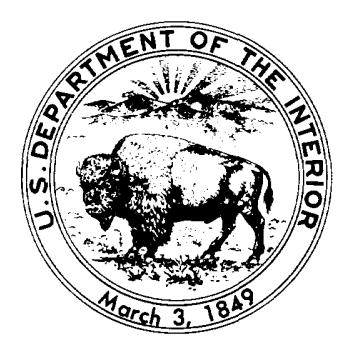

Albuquerque, New Mexico 
DEPARTMENT OF THE INTERIOR

DONALD PAUL HODEL, Secretary

U.S. GEOLOGICAL SURVEY

Dallas L. Peck, Director

For additional information

write to:

District Chief

U.S. Geological Survey

Water Resources Division

Pinetree Office Park

4501 Indian School Rd. NE, Suite 200

Albuquerque, New Mexico 87110
Copies of this report can be purchased from:

U.S. Geological Survey Books and Open-File Reports Section Federal Center

Box 25425

Denver, Colorado 80225 


\section{CONTENTS}

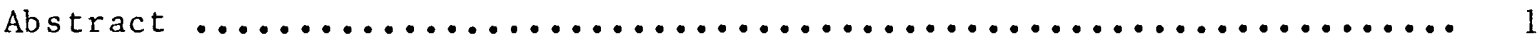

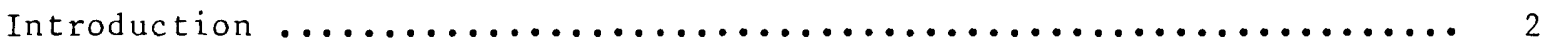

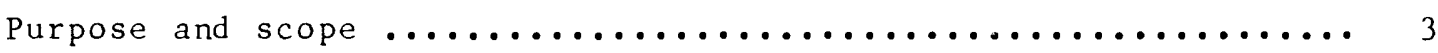

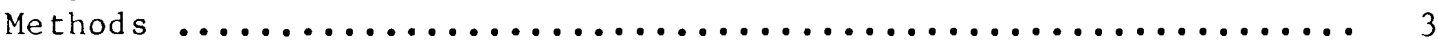

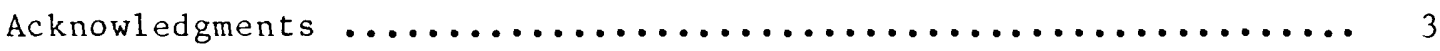

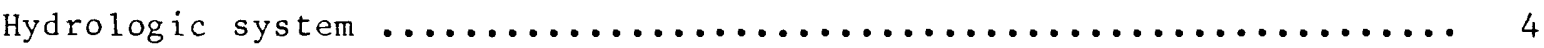

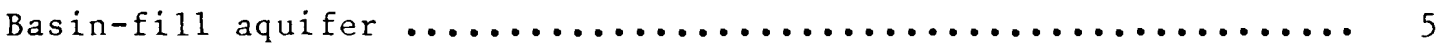

Recharge, discharge, and ground-water flow ................

Influence of humans on ground-water flow .........................

Hydrologic factors limiting the susceptibility of the

ground-water flow system to human activities .................13

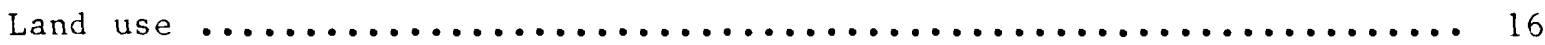

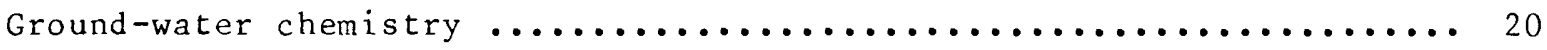

Regional ground-water chemistry ........................ 20

Ground-water chemistry in the Rio Grande valley near

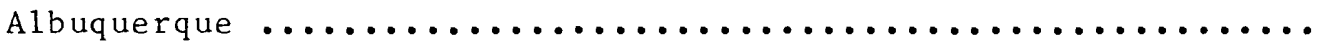

Preliminary evaluation of relation between land use and ground-

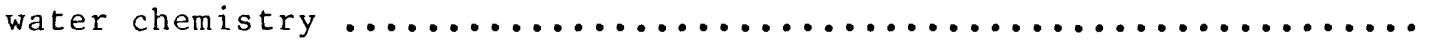

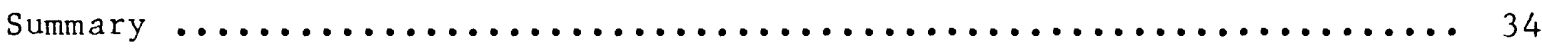

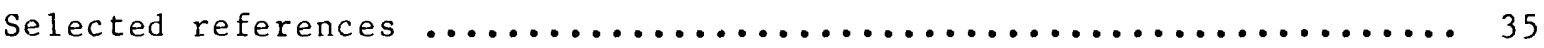

\section{PLATES}

[In pocket]

Plate 1. Map showing depth to water in the Albuquerque-Belen basin, New Mexico

2. Map showing 1 and use and concentrations of dissolved iron and dissolved boron in ground water in the Albuquerque-Belen basin, New Mexico

3. Map showing land use and concentration of selected dissolved constituents in ground water in the Rio Grande valley near Albuquerque, New Mexico 


\section{FIGURES}

Page

Figure 1. Map showing location and physiographic features of the Albuquerque-Belen basin and adjacent areas........... 6

2. Map showing generalized geology of the Albuquerque-Belen basin and adjacent areas $\ldots \ldots \ldots \ldots \ldots \ldots \ldots \ldots \ldots \ldots . \ldots \ldots$

3. Schematic diagram showing recharge to and discharge from

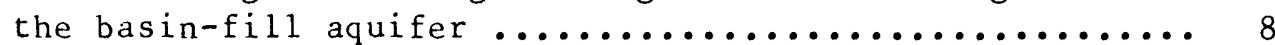

4. Map showing potentiometric surface of the basin-fill aquifer.................................... 11

5. Generalized hydrologic section through the Rio Grande

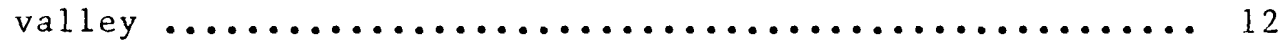

6. Map showing areas where ground water has a relatively high susceptibility to contamination on the basis of

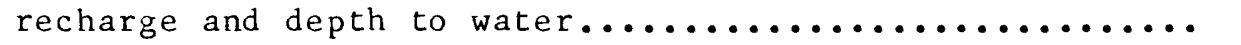

7. Map showing areas where ground water has a relatively high susceptibility to contamination on the basis of

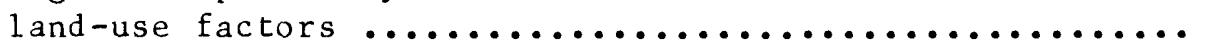

8. Piper diagram of water types $\ldots \ldots \ldots \ldots \ldots \ldots \ldots \ldots \ldots \ldots \ldots$

9. Map showing water-chemistry zones and specific

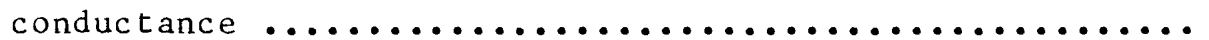

10. Map showing location of the Rio Grande valley near Albuquerque study area

11. Piper diagram of water-chemistry analyses in the U.S.

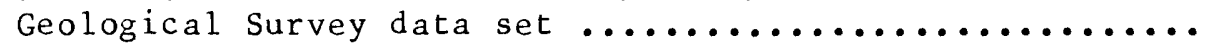

12. Piper diagram of water-chemistry analyses in the Environmental Improvement Division data set $\ldots \ldots \ldots \ldots 28$

13. Map showing location of organic contamination of ground water in the Rio Grande valley near Albuquerque

\section{TABLE}

Table 1. Spearman correlation coefficients for selected dissolved constituents ........................ 


\section{CONVERSION FACTORS}

In this report, measurements are given in inch-pound units only. The following table contains factors for converting to metric units.

\section{Multiply inch-pound units}

inch

foot

mile

acre

acre-foot

gallon

pound per acre per year
$\underline{B y}$

$$
\begin{gathered}
25.40 \\
0.3048 \\
1.609
\end{gathered}
$$$$
4,047
$$$$
1,233
$$

0.003785
0.1836
To obtain metric units

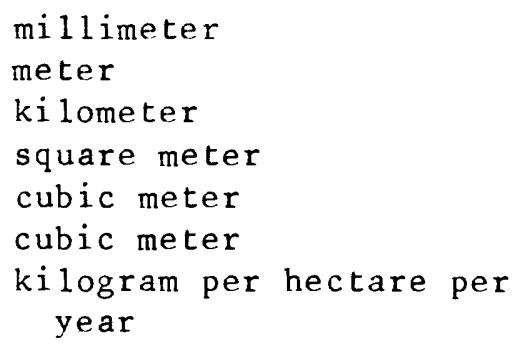

Temperature in degrees Fahrenheit $\left({ }^{\circ} \mathrm{F}\right)$ can be converted to degrees Celsius $\left({ }^{\circ} \mathrm{C}\right)$ as follows:

$$
{ }^{\circ} \mathrm{C}=5 / 9\left({ }^{\circ} \mathrm{F}-32\right)
$$

Sea level: In this report "sea level" refers to the National Geodetic Vertical Datum of 1929 (NGVD of 1929) -- a geodetic datum derived from a general adjustment of the first-order level nets of both the United States and Canada, formerly called "Mean Sea Level of 1929." 


\author{
RECONNAISSANCE OF HYDROLOGY, LAND USE, \\ GROUND-WATER CHEMISTRY, AND EFFECTS OF LAND USE ON \\ GROUND-WATER CHEMISTRY IN THE ALBUQUERQUE-BELEN \\ BASIN, NEW MEXICO \\ By Scott K. Anderho1m
}

\begin{abstract}
In 1984, the U.S. Geological Survey began regional assessments of groundwater contamination in 14 areas, one of which was the Albuquerque-Belen basin. The purpose of this reconnaissance study is to provide information about hydrology, land use, ground-water chemistry, and the effects of land use on ground-water chemistry in the basin.

Ground-water recharge occurs along the basin margins. Ground water flows from the basin margins toward the basin axis and then southward. Ground-water discharge occurs as evapotranspiration in the Rio Grande valley, pumpage, and ground-water flow to the Socorro basin, the alluvial basin to the south.

A map delineating land use was prepared for the entire basin. A more detailed land-use map was prepared for the Rio Grande valley near Albuquerque. Open-space land use, which primarily is used for grazing livestock, occupies the majority of the basin. In the Rio Grande valley, agricultural and residential land uses are predominant; in the area near Albuquerque, the land also is used for commercial, institutional, and industrial purposes.

The Albuquerque-Belen basin was divided into seven zones on the basis of water chemistry. These water-chemistry zones indicate that large variations in water chemistry exist in the basin as the result of natural processes.

Ground water in the majority of the Albuquerque-Belen basin has a relatively low susceptibility to contamination because the depth to water is greater than 100 feet and there is virtually no natural mechanism for recharge to the ground-water system. Ground water in the Rio Grande valley has a relatively high susceptibility to contamination because the depth to water generally is less than 30 feet and there are many types of recharge to the ground-water system.
\end{abstract}


On the basis of possible contaminants associated with types of 1 and use, the basin was divided into areas with low or high susceptibility to contamination resulting from human activities. Ground water in the majority of the basin (open-space land use) has a relatively low susceptibility to contamination. Ground water in the Rio Grande valley has a relatively high susceptibility to contamination.

Changes in land use may cause changes in the chemical composition of recharge to the ground-water system. Dissolved-iron concentrations in the Rio Grande valley near Albuquerque are greater than dissolved-iron concentrations in areas adjacent to the Rio Grande valley near Albuquerque. These relatively large concentrations may result from the change from agricultural land use to residential land use. Recharge associated with agricultural 1 and use is relatively oxidized because the water is in equilibrium with the atmosphere, whereas recharge associated with residential land use (onsite waste-disposal effluent) is relatively reduced and has larger concentrations of organic carbon, biological oxygen demand, and chemical oxygen demand. The constituents in the onsite waste-disposal effluent could cause reducing conditions in the aquifer and the subsequent dissolution of iron and manganese oxides. Trace metals adsorbed to these iron and manganese oxides could be remobilized in ground water after dissolution of the oxides.

\section{INTRODUCTION}

Relatively rapid increases in population in the southwestern United States have resulted in increases in urban areas and increases in demand for ground water for public supply. Ground-water contamination has become a topic for public concern in the arid Southwest because of the limited supplies of surface and ground water.

The alluvial-basins ground-water region occupies a large area in the western and southwestern United States and is the driest region in the United States (Heath, 1984, p. 24). The Albuquerque-Belen basin is representative of the alluvial-basins ground-water region defined by Heath (1984). The mean annual precipitation at the Albuquerque airport is 8.61 inches, although annual precipitation in the mountainous areas adjacent to the basin is as much as three times greater (Gabin and Lesperance, 1977).

The basin-fill aquifer in the Albuquerque-Belen basin consists of interbedded gravel, sand, silt, and clay and is part of a complex streamaquifer system that has been extensively developed in parts of the basin for irrigation, domestic, and municipal water supply. In order for State and local officials to make sound planning decisions related to the water resources in the basin, it is important to understand the effects of increased population and the effects of human activity on the hydrologic system and on ground-water chemistry. 
This study is one of 14 studies that is part of the U.S. Geological Survey's Toxic Waste--Ground-Water Contamination Program. The national program is being conducted to develop methods that will help to assess the quality of the Nation's ground-water reserves and the nature and extent of the ground-water contamination problem (Helsel and Ragone, 1984).

\section{Purpose and Scope}

This report presents the results of a reconnaissance study in the Albuquerque-Belen basin to provide information about the hydrologic system, land use, and ground-water chemistry, and to explain water chemistry in terms of local hydrology and human activities. Included in the report are maps showing the delineation of areas where ground water has a relatively high or low susceptibility to contamination on the basis of hydrologic and land-use factors. Results presented in the report primarily are based on existing data compiled from the U.S. Geological Survey and the New Mexico Environmental Improvement Division.

\section{Methods}

The hydrologic system and distribution of different water chemistries must be understood prior to analysis of the effects of human activities on water chemistry. The Albuquerque-Belen basin is a large area (approximately 100 miles long by 25 to 40 miles wide). The hydrologic system of the area is complex and has a considerable range in ground-water chemistry. Therefore, the ground-water chemistry must be examined in the context of the hydrologic system prior to examining the variations in the context of human activities. For example, differences in hydrologic factors, such as type of recharge, can have significant effects on the distribution of water chemistry. If a recharge type corresponds to a change in land use, the resulting water chemistry might be attributed to land use when the actual cause for the different chemistry is a difference in recharge type, not human activity.

Examination of the hydrologic system also can aid in delineating areas that have a relatively high or low susceptibility to ground-water contamination on the basis of hydrologic factors. Hydrologic factors that are useful in delineating areas of susceptibility to ground-water contamination in the Albuquerque-Belen basin may be transferable to similar areas in the alluvial-basins ground-water region as defined by Heath (1984).

Hydrologic and land-use factors used to classify the susceptibility of the aquifer to contamination indicate that whereas much of the basin has a relatively low susceptibility, one area has a relatively high susceptibility to contamination. This area, which is characterized by varied and changing land-use patterns, was studied more intensively. The relation between 1 and use and susceptibility to contamination may be transferable to other similar alluvial basins.

Acknowledgments

I would like to acknowledge the assistance I received from Joel Wooldridge of the City of Albuquerque Planning Department in obtaining landuse maps of the city of Albuquerque. Data obtained from and discussions with Bruce Gallaher, Dennis McQuillan, and Pat Longmire of the New Mexico Environmental Improvement Division have been most helpful and are greatly appreciated. 


\section{HYDROLOGIC SYSTEM}

The following descriptions of the physiography and geology of the basin and adjacent areas are presented as an aid to understanding the processes that affect the hydrologic system. For a more detailed description of the geology, the reader is referred to Bryan and McCann (1937), Wright (1946), Lambert (1968), and Kelley (1977). For a more detailed description of the hydrologic system, the reader is referred to Theis (1938), Bjorklund and Maxwell (1961), Titus (1961), U.S. Army Corps of Engineers (1979), Kelly (1982), and Kernodle and $\operatorname{Scott}(1986)$.

The Albuquerque-Belen basin is a structural basin that contains the through-flowing Rio Grande in central New Mexico (fig. 1). The basin is bounded on the east by the Sandia, Manzanita, Manzano, and Los Pinos Mountains (fig. 1), which have topographic relief of as much as 5,000 feet above the basin floor. The mountains are fault-block mountains that generally consist of a Precambrian igneous and metamorphic core that is capped by eastwarddipping Paleozoic limestone, sandstone, evaporite deposits, and shale (fig. 2). The Joyita Hills, Socorro basin, and Ladron Peak border the basin on the south (fig. 1). The Joyita Hills have low topographic relief and consist of Paleozoic and Mesozoic evaporite deposits, sandstone, shale, and limestone. The Socorro basin is the adjacent alluvial basin to the south. Ladron Peak has significant topographic relief and is composed of precambrian igneous and metamorphic rock. The western basin boundary consists of the Lucero uplift and the Rio Puerco fault zone (fig. 1). The faults along the western boundary juxtapose Paleozoic limestone, sandstone, shale, and evaporite deposits with basin-fill deposits in the south and Mesozoic sandstone and shale with basin-fill deposits in the north (fig. 2). The Nacimiento uplift, Jemez volcanic complex, and Santo Domingo basin border the basin on the north ( $f i g$. 1). The Nacimiento uplift consists of Precambrian igneous and metamorphic rock, Paleozoic limestone, sandstone, shale, and evaporite deposits, and Mesozoic sandstone and shale. The Jemez volcanic complex, which has topographic relief of as much as 5,000 feet, consists of interbedded volcanic and volcaniclastic sediments. The Santo Domingo basin is the alluvial basin adjacent to the north.

The basin is drained by two main streams, the Rio Grande and the Rio Puerco (fig. 1). The streams are entrenched 200 to 500 feet below a large pediment surface (Kelley, 1977) that extends from the base of the mountains along the eastern border of the basin to the Rio Grande (East Mesa) and between the Rio Grande and the Rio Puerco in a large part of the basin (West Mesa) (fig. 1). The discharge of the Rio Grande is approximately 834,000 acre-feet per year at San Felipe and 669,000 acre-feet per year at San Acacia (Kernodle and Scott, 1986) (fig. 1). The Rio Puerco conveys approximately 35,900 acre-feet of water per year to the Rio Grande (Kernodle and Scott, $1986)$. 
The Jemez River, which has its headwaters in and drains a large part of the Jemez volcanic complex, enters the basin near San Ysidro and joins the Rio Grande near Bernalillo (fig. 1). The Jemez River conveys approximately 33,600 acre-feet of water per year to the Rio Grande (Kernodle and Scott, 1986). The Rio Salado enters the basin in the southern part of the basin and joins the Rio Grande near the southern basin boundary ( $f i g .1$ ). The Rio Salado conveys approximately 9,060 acre-feet per year to the Rio Grande (Kernodle and Scott, 1986).

There are many ephemeral arroyos that enter the basin from adjacent areas. Most of the arroyo channels are relatively wide and deep where the arroyos debouch onto the basin-fill deposits because of the relatively large volumes of water that flow in the arroyos after precipitation. The large volumes of water are the result of runoff from the adjacent, relatively impermeable mountainous areas. Most arroyo channels are not continuous to the Rio Grande because the water rapidly infiltrates through the channel bed and recharges the ground-water system (Bjorklund and Maxwe11, 1961, p. 49).

The basin-fill deposits in the Albuquerque-Belen basin are of late Oligocene to Holocene age (Hawley, 1978, p. 239) and consist of interbedded gravel, sand, silt, and clay. Although the thickness varies considerably because of the large amount of faulting in the basin, the thickness of basinfill deposits in most of the basin is greater than 3,000 feet (Birch, 1982, p. 1,193). In most areas, it is not possible to correlate individual beds or lithologies between wells because of the lenticularity of the beds and the faulting that occurred during and after deposition of the deposits.

\section{Basin-Fill Aquifer}

The basin-fill deposits are the aquifer in the Albuquerque-Belen basin. Values of hydraulic conductivity used in a ground-water flow model of the basin ranged from 0.25 to 50.0 feet per day (Kernodle and Scott, 1986). The aquifer properties have a considerable range of values because of the large variations in the lithology of the basin-fill deposits. Clay layers have relatively small hydraulic conductivity, whereas cobble and gravel deposits have relatively large hydraulic conductivity. Deposits that consist of interbedded gravel, sand, silt, and clay have intermediate hydraulic conductivity. 


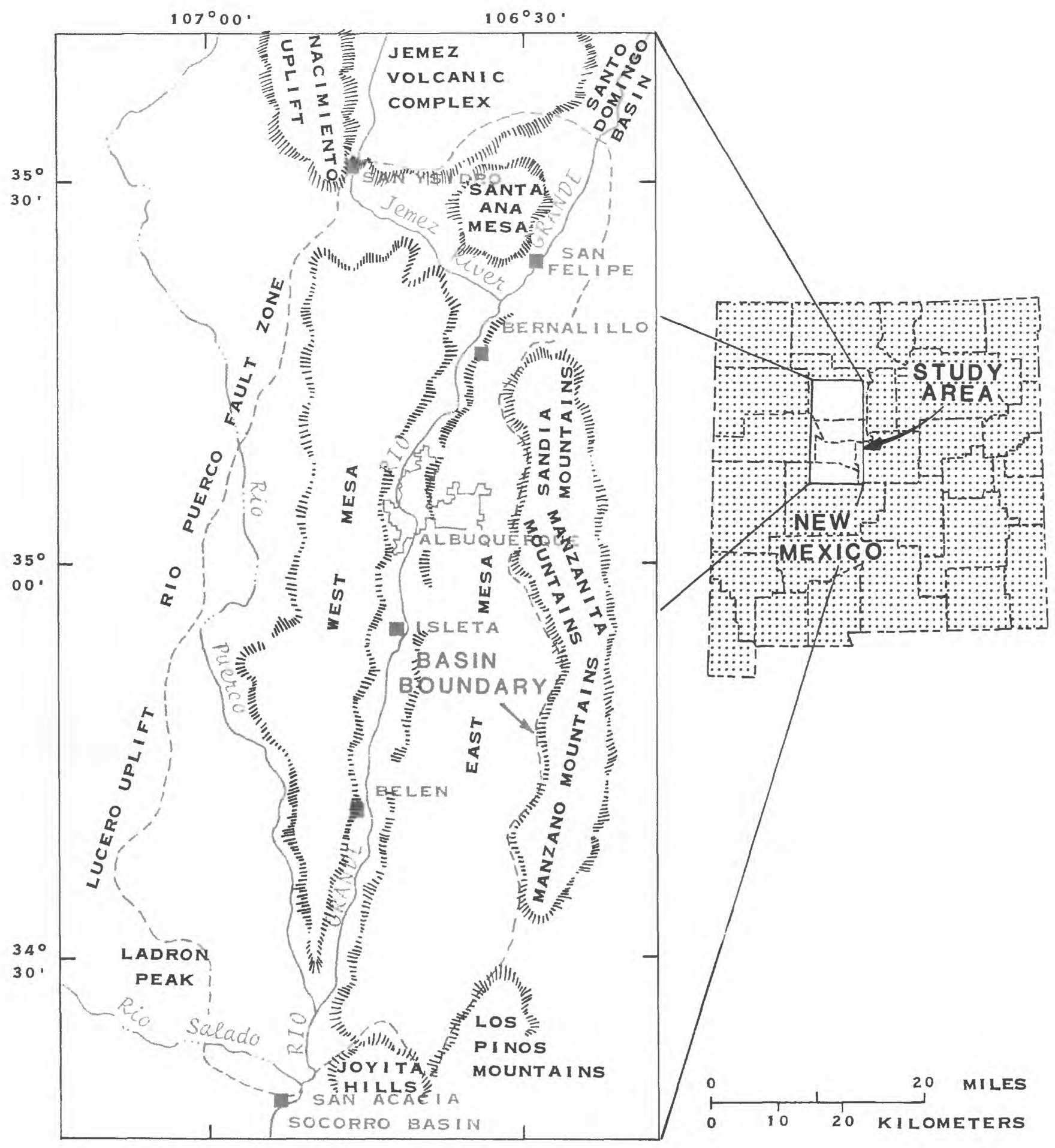

Figure 1.--Location and physiographic features of the Albuquerque-Belen basin and adjacent areas. 


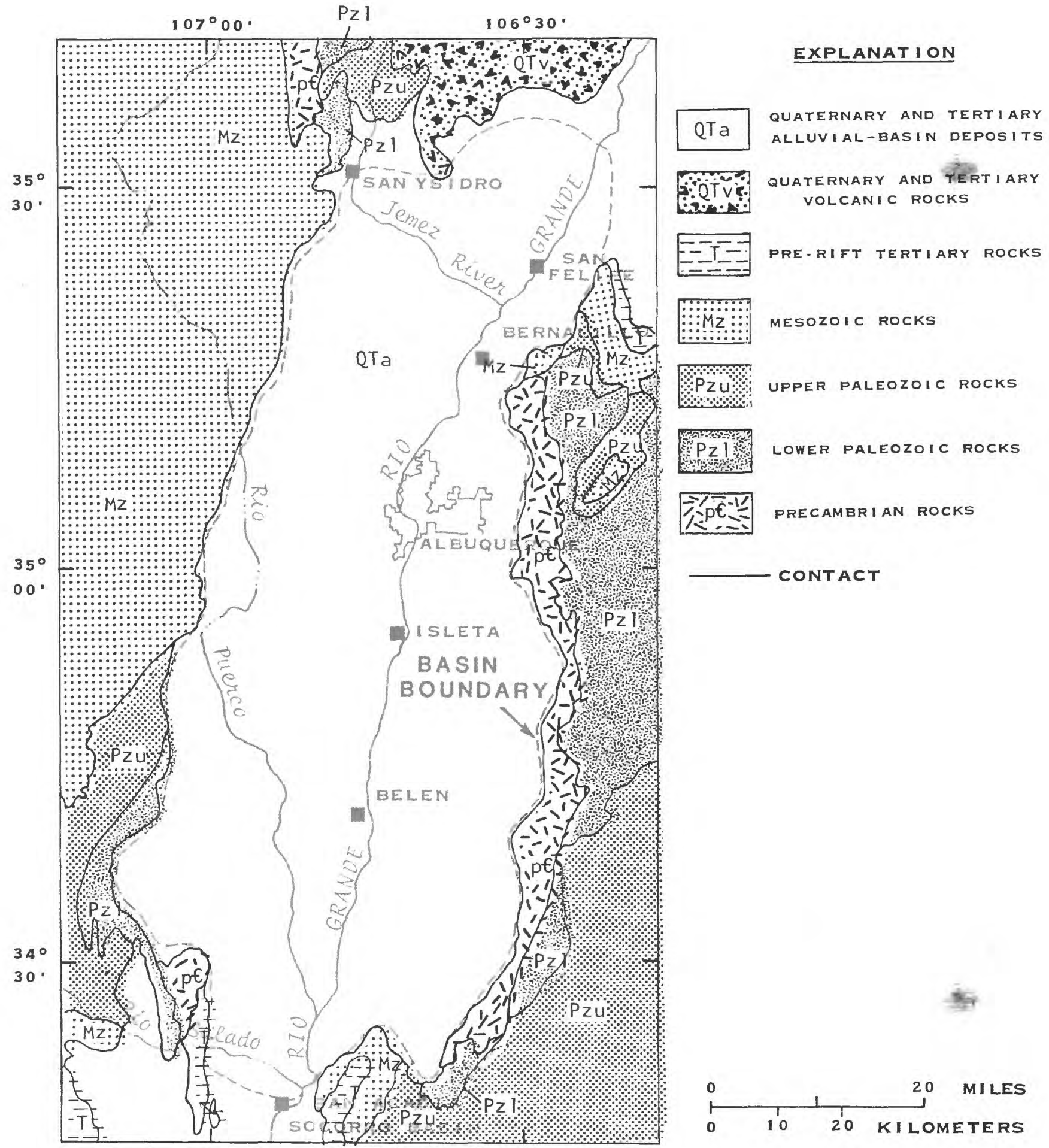

Figure 2.--Generalized geology of the Albuquerque-Belen basin and adjacent areas. 
The four main sources of recharge to the basin-fill aquifer are: (1) Infiltration of surface water from arroyos along the basin margins; (2) infiltration of surface water from intermittent streams; (3) subsurface ground-water inflow; and (4) infiltration of water from the Rio Grande and from excess applied irrigation water ( $\mathrm{fig} .3$ ). Direct infiltration of precipitation also is a minor source of recharge to the basin-fill aquifer.

The majority of the recharge to the basin-fill aquifer is from the infiltration of surface water from arroyos on the basin margins, also called mountain-front recharge. Kernodle and Scott (1986) reported that approximately 129,000 acre-feet per year of water is contributed to the ground-water system by mountain-front recharge. Runoff from precipitation on the relatively impermeable mountainous areas adjacent to the basin infiltrates through channel beds of the arroyos and recharges the basin-fill aquifer. This infiltration occurs in a short distance after the arroyo debouches into the basin as indicated by the decrease in the width of the arroyos after debouching into the basin and the relatively few arroyos that extend from the mountainous areas to the Rio Grande.

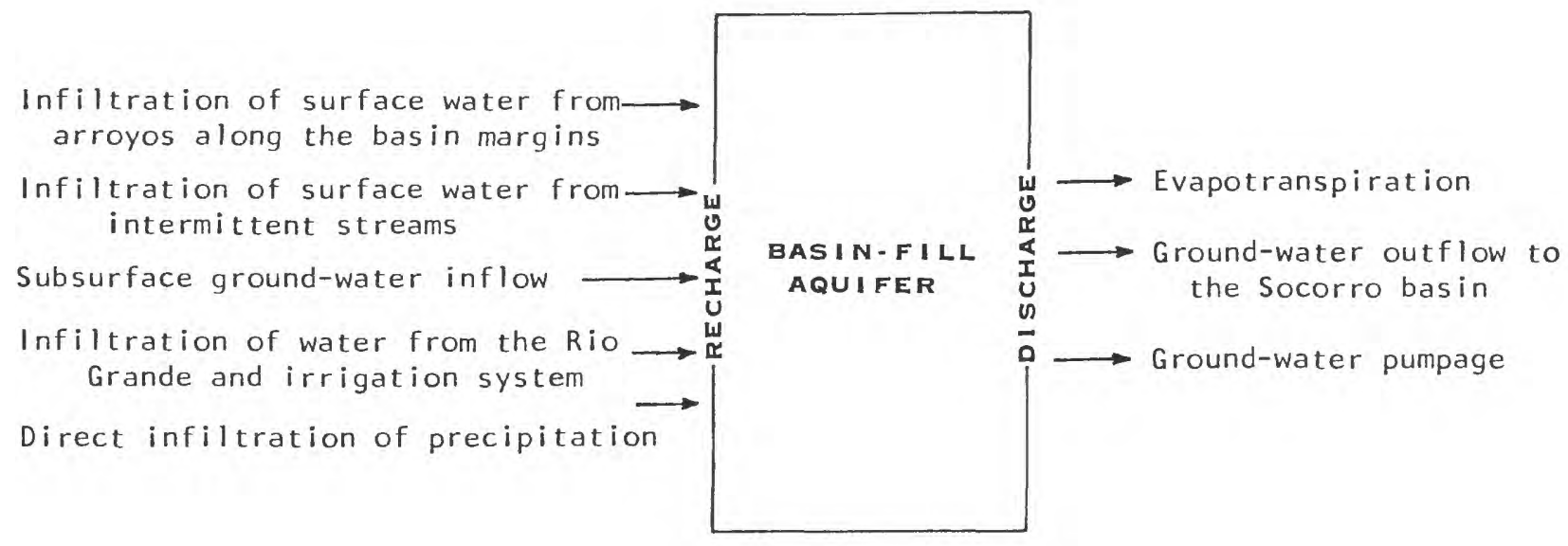

Figure 3.--Recharge to and discharge from the basin-fill aquifer. 
Infiltration of surface water from intermittent streams such as the Rio Puerco, Jemez River, and Rio Salado is another major source of recharge in the basin. In general, these streams are perched for most of their reaches in the basin. Kernodle and Scott (1986) reported that annual recharge to the basinfill aquifer as a result of infiltration of surface water from the Rio Puerco is 10,700 acre-feet, from the Jemez River is 25,000 acre-feet, and from the Rio Salado is 13,500 acre-feet.

Subsurface ground-water inflow recharges the basin-fill aquifer along the northern and southern boundaries of the basin. In the north, ground water flows into the basin from the Jemez volcanic complex and from the adjacent alluvial basin (Santo Domingo basin). Along the southwestern boundary in the Lucero uplift area, ground-water inflow occurs from adjacent paleozoic and Mesozoic rocks. Along the southeastern boundary, ground-water inflow occurs from the Paleozoic and Mesozoic rocks in the Joyita Hills.

Infiltration of excess applied irrigation water is another form of ground-water recharge in the Rio Grande valley and part of the Jemez River valley. The major method of irrigation is flooding with surface water from irrigation canals. Part of the applied water is used by crops and part infiltrates and recharges the basin-fill aquifer (excess applied irrigation water). Infiltration from the Rio Grande and the irrigation canals also is included in this category of recharge. The volume of recharge resulting from infiltration of excess applied irrigation water is not possible to accurately estimate because of the complex hydrology in the Rio Grande valley.

Direct infiltration of precipitation is a minor source of recharge. Large areas of the basin are underlain by a very extensive caliche layer. It is thought that very little water infiltrates through this caliche (Jack Dewey, U.S. Geological Survey, oral commun., 1985). Some direct infiltration of precipitation probably occurs in areas where permeable deposits such as sand dunes, gravel layers, or volcanic rock are exposed at the surface, but this volume of recharge probably is small compared to the quantity of recharge from the other sources.

Discharge from the basin-fill aquifer is the result of three major processes: (1) evapotranspiration, (2) ground-water outflow to the Socorro basin, and (3) ground-water pumpage (fig. 3). Evapotranspiration probably accounts for the largest amount of ground-water discharge. Kernodle and Scott (1986) estimated approximately 350,000 acre-feet of evapotranspiration occurs annually in the Albuquerque-Belen basin. Most of the evapotranspiration occurs in the Rio Grande valley where the depth to water is shallow enough to permit growth of phreatophytes and where most of the irrigation occurs. 
Subsurface ground-water flow to the adjacent alluvial basin (Socorro basin) also is a major form of ground-water discharge. The quantity of this discharge is not well known because the hydraulic gradients, cross-sectional area of ground-water flow, and hydraulic conductivity of basin-fill deposits are not well known. In their ground-water flow model, Kernodle and Scott (1986) estimated that there is approximately 14,600 acre-feet per year of ground-water outflow to the Socorro basin.

Pumpage also is a major discharge from the basin-fill aquifer. Groundwater pumpage for domestic use in the Rio Grande valley probably has little effect on ground-water levels. The volume of water removed from the aquifer probably is not large at any one location, and the water removed probably is replaced quickly by infiltration of excess applied irrigation water. Municipal pumpage near the major population centers does have a significant effect on ground-water levels (Kelly, 1982).

Ground water generally is unconfined in the upper part of the aquifer. Ground water in the deeper parts of the aquifer is semiconfined or confined because of anisotropy in the aquifer (Kernodle and Scott, 1986). Kernodle and Scott (1986) used a vertical to horizontal hydraulic-conductivity ratio of 1:500 in their ground-water flow model of the basin.

The depth to water varies considerably in the basin. The depth to water in the Rio Grande valley and the Jemez River valley generally is less than 30 feet ( $\mathrm{p} 1.1)$. In many parts of the Rio Grande valley, the depth to water is less than 10 feet. In areas on the East and West Mesas, the depth to water generally is greater than 300 feet; in some areas on the West Mesa, the depth to water is almost 900 feet.

The direction of ground-water flow generally is from the basin margins toward the basin center (fig. 4). Ground water also flows southward toward the Socorro basin (fig. 4). Ground water in the vicinity of the Jemez River flows southeastward approximately parallel to the Jemez River (fig. 4).

Titus (1961) described a ground-water trough west of the Rio Grande that extends from Belen to approximately the same latitude as Bernalillo (fig. 4). However, the existence of this trough was based on few data. If the trough exists, ground water flows from the Rio Grande valley westward toward the trough.

Hydraulic gradients are steep along the western basin margin and relatively flat near the center of the basin (fig. 4). Ground water along the eastern side of the basin is perched on a structural bench composed of Paleozoic and Mesozoic rocks that are covered with a veneer of basin-fill deposits. In some areas along the bench, there is a difference in water levels of approximately 500 feet across a fault that separates the bench from a thick section of more permeable basin-fill deposits to the west. 


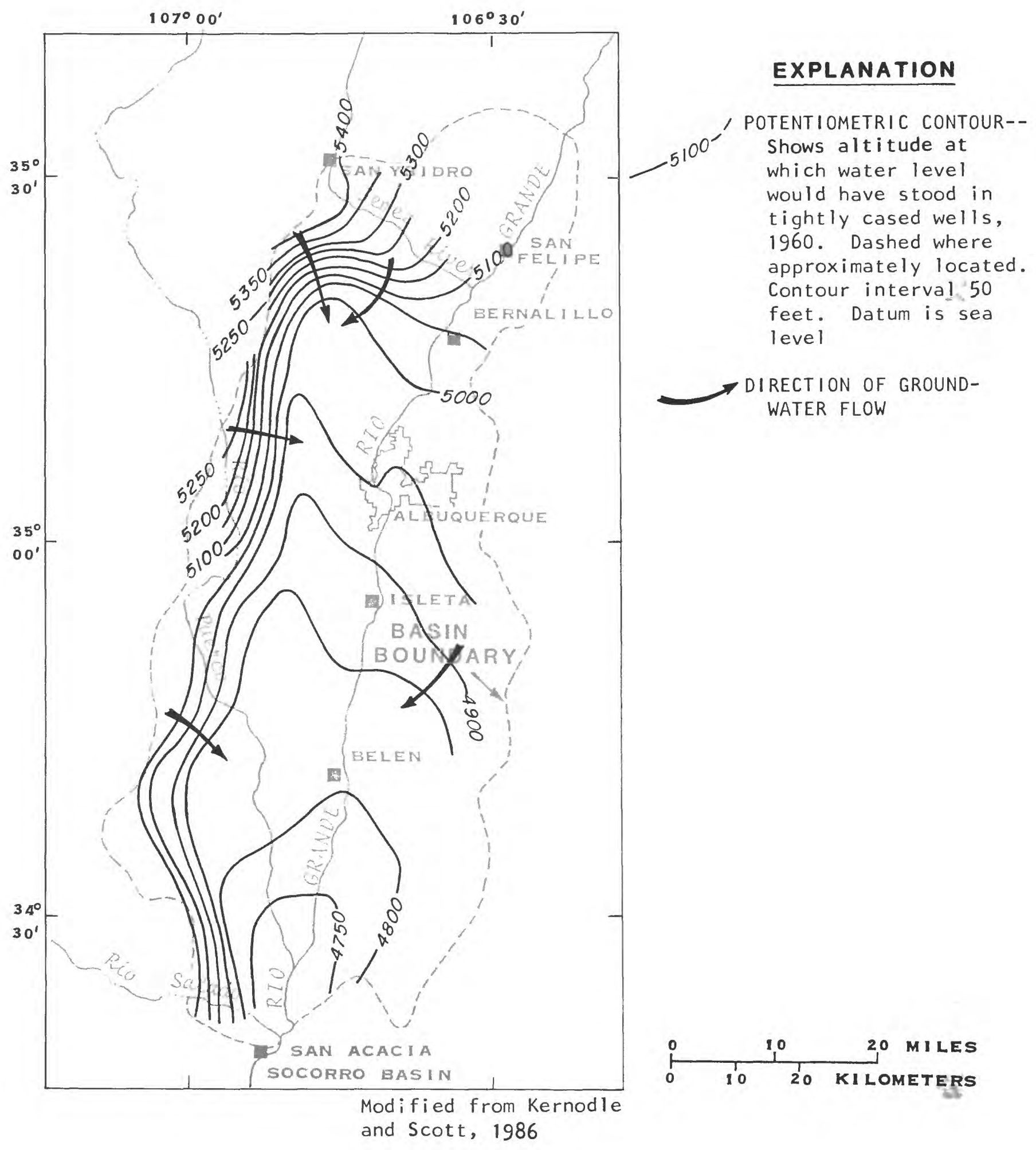

Figure 4.--Potentiometric surface of the basin-fill aquifer. 


\section{Influence of Humans on Ground-Water Flow}

As mentioned in the previous section, humans have affected the groundwater flow system by adding recharge to the system with excess applied irrigation water and by increasing discharge from the system with municipal well pumpage. The changes by irrigation are limited to the Rio Grande valley. The majority of the pumpage has taken place east of the Rio Grande in Albuquerque.

Prior to the construction of the irrigation system, ground water in the valley flowed parallel to the Rio Grande (Theis, 1938, p. 291). In some areas, there was little movement of ground water to the valley from the regional flow system (Theis, 1938, p. 291). In general, water levels in the valley were higher before construction of the irrigation system than after construction ( The is, 1938, p. 272).

The irrigation system consists of an extensive system of canals and drains (fig. 5). The canals deliver water from the Rio Grande to the irrigated fields. The surface drains are designed to remove the excess applied irrigation water from the shallow ground-water system and return the water to the Rio Grande (fig. 5) in order to prevent crop damage by waterlogging. There also are riverside drains on both sides of the Rio Grande. The altitude of the bottom of these drains generally is lower than the altitude of the Rio Grande so that water that infiltrates from the Rio Grande does not cause permanent rises in ground-water levels (and subsequent waterlogging of soils adjacent to the Rio Grande) but is intercepted by the riverside drains and returned to the Rio Grande downstream.

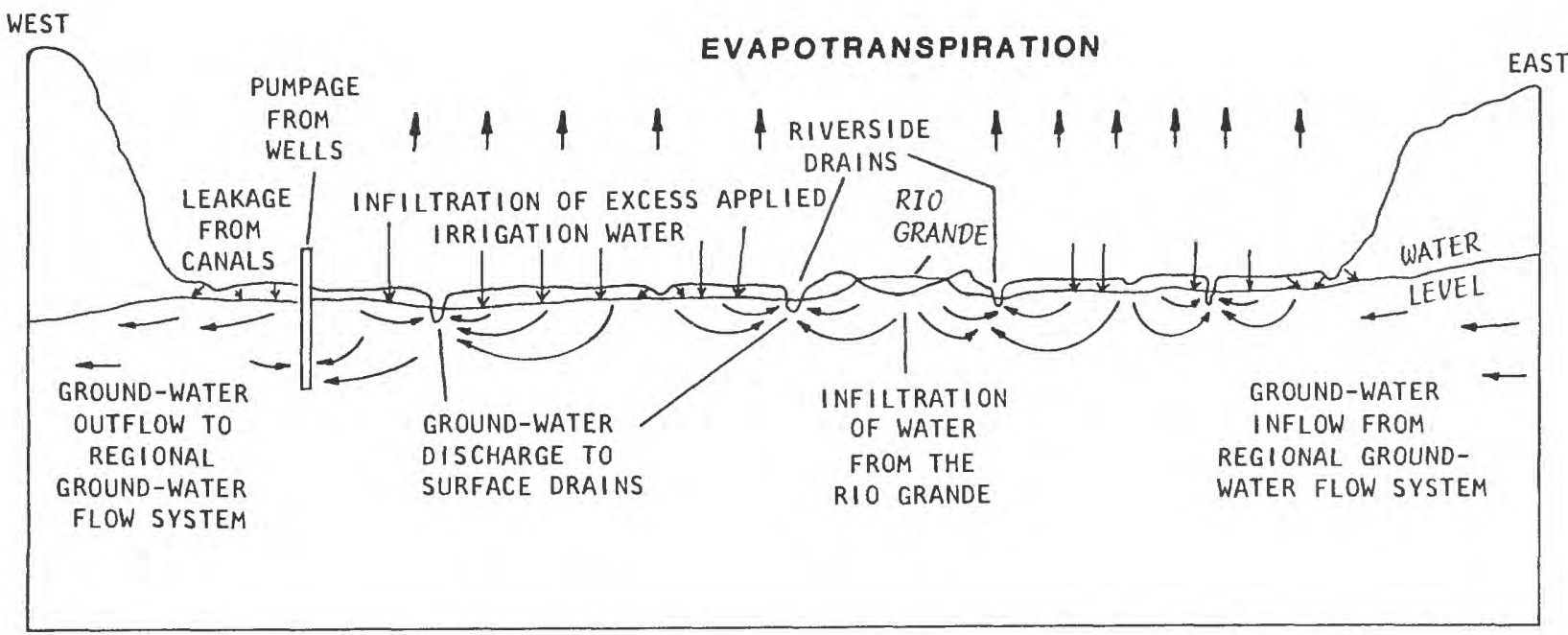

NOT TO SCALE

Figure 5.--Generalized hydrologic section through the Rio Grande valley. 
Ground-water pumpage for municipal use also has modified the ground-water flow system in the basin. Kelly (1982, p. 354) reported that drawdowns in wells in the Albuquerque area in 1978 were as great as 130 feet. In general, water levels in Albuquerque east of the Rio Grande have declined approximately 40 feet (Kelly, 1982). These water-level declines have reversed the direction of ground-water flow in the Albuquerque area. Ground water presently (1985) flows from the Rio Grande valley eastward toward major well fields in the city. Ground-water pumpage probably also has caused downward hydraulic gradients in the Albuquerque area because wells are screened relatively deep in the aquifer.

The present (1985) ground-water flow system in the Rio Grande valley is complex because of effects caused by the interaction of the irrigation system, the Rio Grande, pumpage by wells, and evapotranspiration. It is not easy to predict the direction of ground-water flow in the shallow system because of the difficulty of estimating the location and magnitudes of recharge and discharge.

\section{Hydrologic Factors Limiting the Susceptibility of the Ground-Water Flow System to Human Activities}

Hydrologic factors such as areal recharge and depth to water can be used to classify areas that are less susceptible to ground-water contamination from human activities. If recharge does not occur in an area, the process to transport contaminants down through the unsaturated zone to the ground-water flow system does not exist. Areal recharge occurs as infiltration of surface water from arroyos along the basin margins, from rivers and intermittent streams, and from excess applied irrigation water. Areal recharge does not occur in large areas of the basin, so the susceptibility of ground water to contamination is relatively low in these areas.

The time required for a contaminant to travel through the unsaturated zone is related to the thickness of the unsaturated zone (depth to water) and quantity of recharge. A large depth to water and resulting long travel time for a contaminant would minimize the effect of some contaminants because of degradation and adsorption of the contaminants on deposits of the unsaturated zone. 
Artificial recharge due to leaking storage tanks or waste-disposal pits could result in contamination of the ground water. The quantity of contaminant required to cause contamination of ground water, assuming the contaminant is insoluble in water, is related to depth to water by the following equation (Freeze and Cherry, 1979, p. 446):

$$
\mathrm{B}_{\mathrm{O}}=\mathrm{B} \mathrm{N} \mathrm{S}_{\mathrm{O}}
$$

where

$$
\begin{aligned}
& \mathrm{B}_{\mathrm{O}} \text { is the amount of contaminant per unit area (thickness of } \\
& \text { contaminant per unit area); } \\
& \mathrm{B} \text { is the depth to water; } \\
& \mathrm{N} \text { is the porosity of unsaturated material; and } \\
& \mathrm{S}_{\mathrm{O}} \text { is the residual saturation of the contaminant. }
\end{aligned}
$$

For an assumed depth to water of 100 feet, a porosity of 0.3 , and residual saturation of the contaminant of 0.2 , from the above equation, the thickness of a contaminant required just to reach the ground water is 6 feet per unit area. For a leaking waste-disposal pit 10 feet square it would require infiltration of approximately 4,500 gallons of contaminant just to reach residual saturation of the unsaturated zone. If the contaminant is soluble in water, the quantity of contaminant is considerably less. However, recharge would have to coincide with the area of the pollutant to dissolve and transport it through the unsaturated zone.

Large areas of the Albuquerque-Belen basin and also of the arid southwestern United states have a relatively low susceptibility to groundwater contamination on the basis of recharge and depth to water. Areas in the basin where recharge occurs and the depth to water is less than 100 feet are delineated in figure 6. These are the areas that are more susceptible to contamination. 

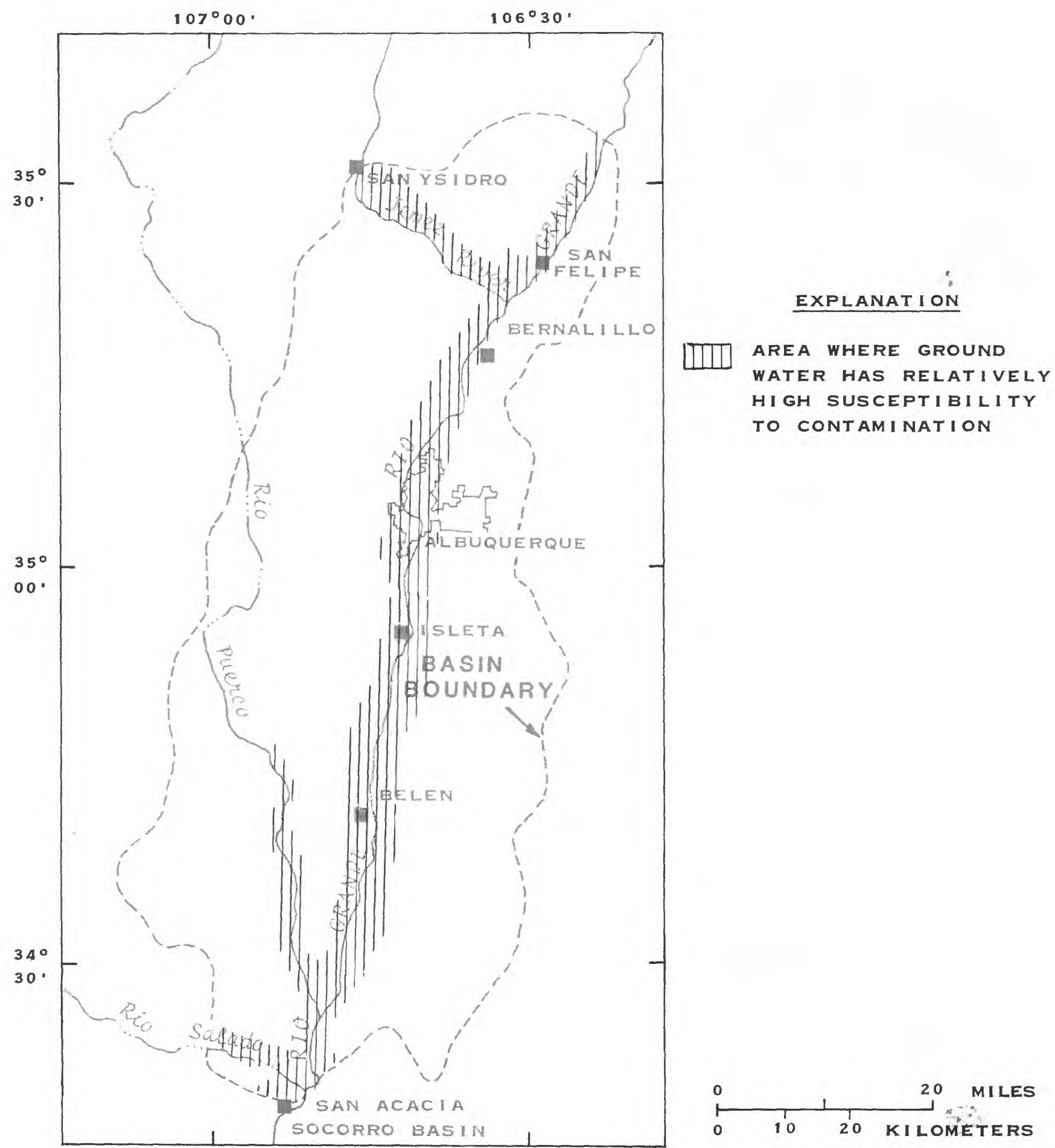

Figure 6.--Areas where ground water has a relatively high susceptibility to contamination on the basis of recharge and depth to water. 


\section{LAND USE}

Land-use maps for the entire basin (Middle Rio Grande Council of Governments of New Mexico, 1978) and for the Rio Grande valley near Albuquerque (Albuquerque Municipal Development Department, 1985) are shown on plates 2 and 3. Different land-use categories are delineated on the plates because of the degree of detail that can be shown at each map scale and because of the different sources of the maps. Some field checking of the maps was done, but in general there were few changes made. Individual land-use categories will be explained in sufficient detail in the following paragraphs to provide a general understanding of each category. Further explanation of land-use categories is contained in publications by the U.S. Department of Commerce (1965) and Anderson and others (1976).

Land-use categories for the basin include urbanizing residential; agricultural and rural residential; commercial and business; special use; industrial, manufacturing, and warehousing; and open space ( 1.2 ). Urbanizing-residential land use varies from multifamily apartments to singlefamily homes on lots larger than 1 acre. A large percentage of the urbanizing-residential category is near the towns and cities in the Rio Grande valley. Agricultural and rural-residential land primarily is used for agriculture and also is in the Rio Grande valley. Delineation between urbanizing-residential and agricultural and rural-residential land use is difficult because there is a complete spectrum between agricultural and residential land use.

Commercial and business areas predominantly are used for the sale of products and services. These areas generally are adjacent to urbanizingresidential land use. The special-use category includes major recreation sites, airports, institutional facilities, and military facilities. Most of this land use is near Albuquerque. The industrial, manufacturing, and warehousing land-use category includes a considerable array of land uses from heavy industry to storage facilities. These areas generally are along major transportation routes and almost entirely are confined to the Albuquerque area.

Open space is the most extensive land-use category in the basin. Open space is a broad category that includes range land, Indian reservations, flood plains, and undeveloped parts of urban areas.

A detailed land-use map of the Rio Grande valley near Albuquerque ( $p 1.3$ ) by the Albuquerque Municipal Development Department (1985) was prepared from aerial photography and zoning information. Some verification was done. Land use was categorized according to a slightly revised version of the Standard Land Use Coding Manual of the U.S. Department of Commerce (1965) used by the City of Albuquerque. Land-use categories delineated in the Rio Grande valley near Albuquerque include agricultural, commercial, light industry, heavy industry, institutional, open space or recreational, parks, single-family residential, multifamily residential, and vacant. 
Agricultural land use includes areas where agricultural practices predominate, although some rural homesites are included in this category. Agricultural areas range in size from a few acres to a few hundred acres. Commercial land use consists of areas predominantly used for the sale of products and services, including shopping centers, restaurants, gasoline stations, laundries, business services, and professional services.

Light industry consists of wholesale, warehouse, and open storage facilities. This category includes junk yards, lumber yards, tank farms, and establishments that sell mechandise to retailers. Heavy industry generally includes businesses that use raw materials to manufacture products, although railroad yards are included in this category. Institutional land includes schools, religious facilities, government facilities, medical facilities, and cultural facilities such as art galleries, libraries, and community centers. The open-space and parks land-use categories include major parks, golf courses, and playing fields. Single-family residential includes mobile homes that are not in courts, whereas multifamily residential includes mobile home courts.

In order to summarize the potential effect on ground-water chemistry associated with different land uses, the various land-use categories on plates 2 and 3 were combined into five more general categories: Agricultural and rural residential, commercial and institutional, industrial, urbanizingresidential and residential, and open space. These categories are based on similarities in potential contaminants.

Agricultural and rural-residential land use is limited to the Rio Grande valley and the Jemez River valley. Potential contaminants associated with this land use are fertilizers and organic compounds used for weed and pest control. Infiltration of effluent from onsite waste-disposal systems also could be a possible contaminant. The density of homes in this land-use category is low; thus, this source of contamination would have a minimal effect on ground-water chemistry. Infiltration of excess applied irrigation water also could have an effect on the shallow ground-water chemistry.

Commercial and institutional land use is restricted to the Rio Grande valley and Albuquerque area. Infiltration of storm runoff from paved areas, infiltration of waste products from laundry facilities, and infiltration of gasoline from leaking gasoline storage tanks are the major potential sources of contamination.

Industry generally is restricted to the Albuquerque area. Possible contaminants associated with industry are organic solvents, petroleum products, or other by-products of manufacturing processes. The specific contaminants would be dependent on the type of industry. 
Urbanizing residential and residential land use generally is in the Rio Grande valley and in the Albuquerque area. Potential contaminants include fertilizers and organic chemicals used on lawns and gardens, which could infiltrate and reach the water table. In addition, in some areas in the valley near Albuquerque, a municipal sewage system is not available or residences are not connected to the system. In these areas, the residences have onsite domestic waste-disposal systems (septic tanks or cesspools).

The composition of effluent from onsite waste-disposal systems varies but generally has increased concentrations of chloride, sodium, bicarbonate, nitrogen, phosphorous, chemical oxygen demand (COD), biological oxygen demand (BOD), and total organic carbon (TOC) relative to the supply water (Metcalf and Eddy, Inc., 1972, p. 231). Increases can range from 250 to 1,000 milligrams per liter for COD, 100 to 300 milligrams per 1 iter for BOD, and 100 to 300 milligrams per liter for TOC (Metcalf and Eddy, Inc., 1972, p. 231). The loading of these contaminants on the ground-water system from recharge of onsite waste-disposal system effluent varies because of the large variation in density of individual disposal systems. For example, assuming that all wastewater recharges the aquifer, that there are four houses per acre, that 250 milligrams per liter is the average TOC concentration in wastewater, and that there are 500 gallons of wastewater per day per house, the TOC loading on ground water would be 1,523 pounds per acre per year.

Ground water in areas corresponding to open-space land use, which occupies the majority of the basin, primarily is used for grazing livestock. The land will not support large numbers of livestock per acre, so the density of livestock is low. Potential contaminants include nitrate and coliform bacteria.

On the basis of the preceding descriptions, land-use categories were used to divide the basin into areas where ground water has a relatively low or high susceptibility to contamination from human activities. Areas corresponding to open-space land use were classified as having a relatively low susceptibility to ground-water contamination. All other land uses were classified as having a relatively high susceptibility to ground-water contamination ( $f$ ig. 7 ). 

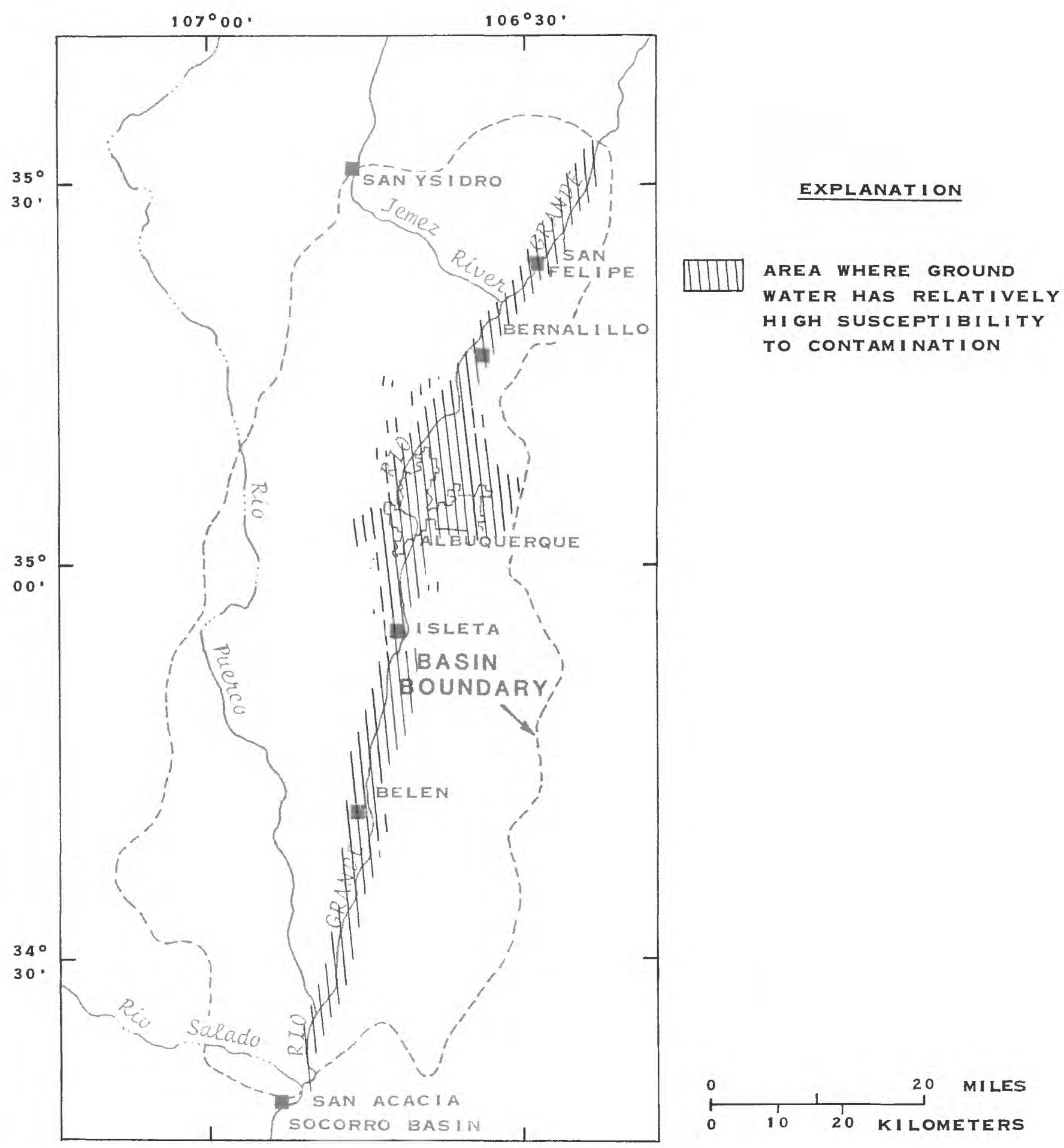

Figure 7.--Areas where ground water has a relatively high susceptibility to contamination on the basis of land-use factors. 


\section{GROUND-WATER CHEMISTRY}

The ground-water chemistry in the Albuquerque-Belen basin was examined on a regional scale and on a local scale. The ground-water chemistry was studied on a regional scale even though hydrologic and land-use factors indicate that ground water in a majority of the basin has a relatively low susceptibility to contamination resulting from human activities. Natural or regional waterchemistry variations need to be understood before the effects of human activities on ground-water chemistry $c$ an be analyzed. The Rio Grande valley near Albuquerque was studied on a local scale because ground water in the area has a relatively high susceptibility to contamination from human activities. Results of the regional-scale ground-water-chemistry investigation indicate that in a majority of the basin there are no ground-water-quality anomalies that $c$ an be attributed to human activities. There is a relatively large water-quality data base for the area so substantial time and large amounts of money were not needed for data collection. The area is similar to other areas in the alluvial-basins ground-water region where population is increasing and there is varied and changing land use.

Three different data sets were used in the analysis. The data set used for the entire basin consisted of U.S. Geological Survey data from the WATSTORE system. Another data set consisted of U.S. Geological Survey data from the WATSTORE system for the Rio Grande valley near Albuquerque. Data were compiled from the New Mexico State Environmental Improvement Division to create an additional data set for the Rio Grande valley. Data in some areas were so extensive that deletion of some of the data was necessary. In these areas, data were examined and representative chemical analyses were selected.

\section{Regional Ground-Water Chemistry}

Water types have been identified in the Albuquerque-Belen basin regionalscale investigation on the basis of the dominant dissolved anions and cations. The different water types were chosen with the aid of Piper diagrams (Piper, 1944) and are based on the concept of hydrochemical facies as described by Back (1961). Seven water types were selected on the basis of the distribution of cations, and seven water types were selected on the basis of the distribution of anions ( $\mathrm{fig} \cdot 8$ ).

The basin was divided into seven water-chemistry zones on the basis of water types (fig. 9). Some zones have two different water types, and it is not possible to subdivide these zones into zones with a single water type. Not every water analysis from a particular zone belongs in the water type for that zone, but the majority of the analyses do. Small areas with a different water type may exist within a designated zone, but it was not possible to delineate all the water types in the regional analysis. For ease of discussion, the water-chemistry zones are referred to by the numbers shown in figure 9 . 


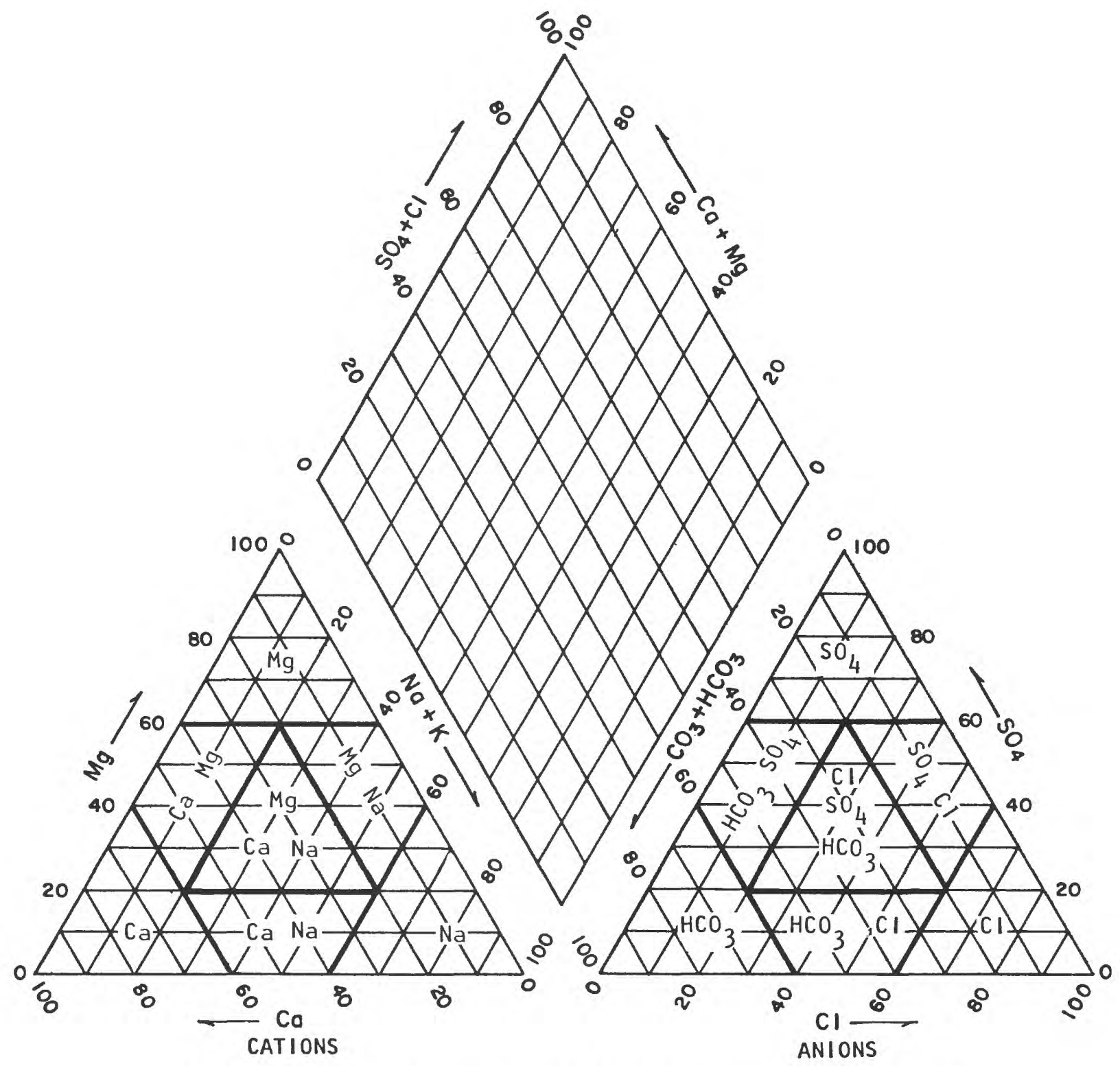

PERCENTAGE OF TOTAL IONS, IN MILLIEQUIVALENTS PER LITER

CATIONS

$\begin{array}{ll}\mathrm{Ca} & \text { Calcium } \\ \mathrm{Na} & \text { Sodium } \\ \mathrm{Mg} & \text { Magnesium } \\ \mathrm{K} & \text { Potassium }\end{array}$

ANIONS

$\begin{array}{ll}\mathrm{Cl} & \text { Chloride } \\ \mathrm{SO}_{4} & \text { Sulfate } \\ \mathrm{CO}_{3} & \text { Carbonate } \\ \mathrm{HCO}_{3} & \text { Bicarbonate }\end{array}$

Figure 8.--Piper diagram of water types. 

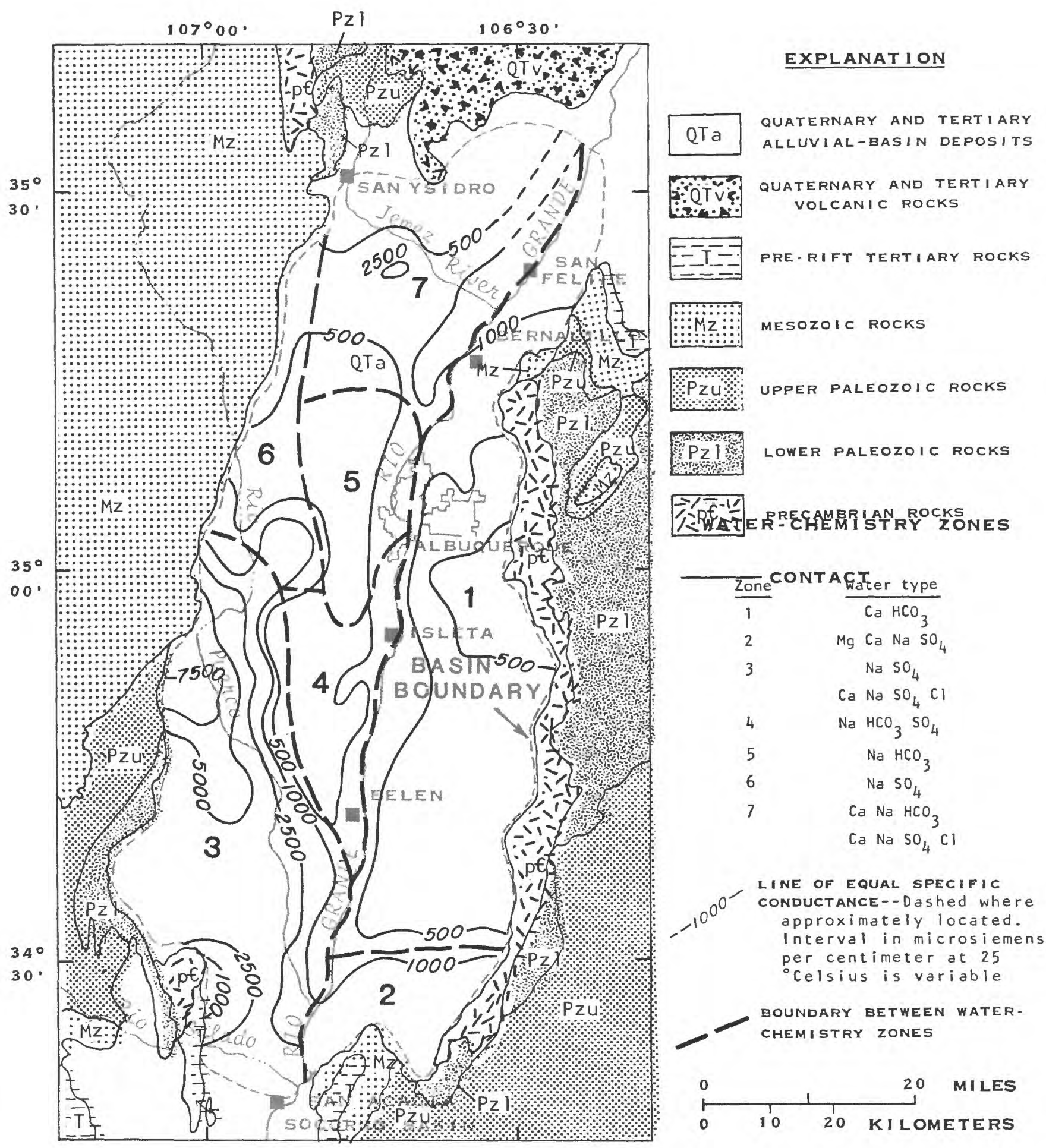

Figure 9.--Water-chemistry zones and specific conductance. 
Ground water in zone 1 , east of the Rio Grande in the central and northern part of the basin (fig. 9), is a calcium bicarbonate type. The specific conductance generally is less than 500 microsiemens per centimeter at $25^{\circ}$ Celsius except near the Rio Grande where evapotranspiration occurs in the river valley. Mountain-front recharge derived from Precambrian and Paleozoic rocks along the eastern side of the basin is the major factor affecting ground-water chemistry in this area.

Ground water in zone 2, east of the Rio Grande in the southern part of the basin, is a magnesium calcium sodium sulfate type. The specific conductance generally is greater than 1,000 microsiemens per centimeter (fig. 9). Mountain-front recharge derived from Paleozoic and Mesozoic rocks is the major factor affecting ground-water chemistry in the area. The large specific conductance in this area in comparison to zone 1 is caused by the difference in the composition of mountain-front recharge.

Ground water in the southwestern part of the basin, zone 3 , is of two types, sodium sulfate and calcium sodium sulfate chloride (fig. 9). The specific conductance generally is greater than 2,500 microsiemens per centimeter. The ground-water chemistry in this area is affected by inflow of ground water from adjacent bedrock units and from mountain-front recharge. This inflow is indicated by the presence of springs along the basin boundary that discharge sodium chloride water that has a specific conductance of approximately 35,000 microsiemens per centimeter. The area with specific conductance of less than 2,500 microsiemens per centimeter in the southwestern corner is affected by mountain-front recharge from the Precambrian rock of Ladron Peak.

Ground water in zone 4, between the Rio Grande and zone 3, is a sodium bicarbonate sulfate type (fig. 9). The specific conductance generally is less than 500 microsiemens. Ground water in this area probably represents water that has flowed westward from zone 1. The change in water type between zone 1 and zone 4 probably is the result of cation exchange and some gypsum dissolution.

Ground water west of Albuquerque, zone 5, is a sodium bicarbonate type. The specific conductance generally is less than 500 microsiemens per centimeter (fig. 9). Ground water in this zone is affected by cation exchange. Specific-conductance increases near the Rio Grande in this zone and in zone 4 probably are due to the effect of excess applied irrigation water.

Ground water in zone 6 , in the northwestern part of the basin, is a sodium sulfate type. The specific conductance of ground water varies from less than 500 to more than 2,500 microsiemens per centimeter (fig.9). Ground water in this zone probably is affected by inflow of ground water from Mesozoic rock west of the basin. Hydraulic gradients indicate that flow is from west to east in this zone ( $\mathrm{fig} .4$ ). 
Ground water in the northern part of the basin, zone 7, is of two types, calcium sodium bicarbonate and calcium sodium sulfate chloride (fig. 9). There is a large range in specific conductance in ground water in this area, but the specific conductance generally is less than 1,000 microsiemens per centimeter. Ground water probably is affected by inflow of ground water from the Jemez volcanic complex and the Santo Domingo basin, as indicated by water levels in the area (Titus, 1961; and Craigg, 1984).

Dissolved trace-element concentrations in ground water also were examined. The density of data and number of elements analyzed were variable. Examination of the data indicates areal trends for boron and iron concentrations.

The largest boron concentrations are along the southwestern side of the basin and in the northern part of the basin (pl. 2). The large boron concentrations in the southwest are caused by inflow of ground water with large boron concentrations from adjacent bedrock units west of the basin boundary ( $\mathrm{pl} .2$, fig. 4). The large boron concentrations in the northern part of the basin probably reflect inflow from the Jemez volcanic complex or the Jemez geothermal reservoir. The three analyses from the Jemez area north of the basin boundary have a considerable range of boron concentrations, but one sample has a boron concentration of 3,300 micrograms per liter (pl. 2). In addition, the potentiometric-surface map indicates that ground-water flow is from the Jemez area southward into the basin (fig. 4).

Ground water from several areas along the southwestern side of the basin has iron concentrations greater than 100 micrograms per liter (pl. 2). Areas with iron concentrations greater than 100 micrograms per liter generally are close to the basin boundary, indicating that this water may be representative of ground water entering the basin (subsurface inflow). The dissolved-iron concentrations also may be caused by natural conditions in the aquifer that result in large solubilities of iron.

Ground water from several wells in the northern part of the basin also has large iron concentrations ( $\mathrm{pl}, 2)$. These large iron concentrations probably are due to inflow from the Jemez volcanic complex or the Jemez geothermal reservoir, as indicated by the large iron concentrations in water north of the Jemez River $(\mathrm{pl}, 2)$.

Iron concentrations are relatively large in the Rio Grande valley, especially in the Albuquerque area (pl. 2). The large iron concentrations are in areas of the Rio Grande valley where land uses are varied. Water from wells in the Rio Grande valley where land use is less varied (mainly agricultural and rural residential or open space) generally does not have iron 
concentrations greater than 100 micrograms per liter. Iron concentrations in ground water east and west of the Rio Grande valley near Albuquerque generally are less than 70 micrograms per liter, whereas iron concentrations in ground water in the Rio Grande valley generally are greater than 100 micrograms per liter (pl. 2). Several factors could result in the larger iron concentrations in ground water in the Rio Grande valley. More carbonaceous material in sediments in the Rio Grande valley in comparison to the areas adjacent to the valley could result in more reducing conditions in the valley. The more reducing conditions could result in greater solubilities for iron. The large dissolved-iron concentrations also may be the result of human activities in the valley.

\section{Ground-Water Chemistry in the Rio Grande Valley near Albuquerque}

The Rio Grande valley near Albuquerque study area (fig. 10 ) is bounded on the east and west by the upland areas adjacent to the Rio Grande valley, on the north by Ranchitos Road, and on the south by Interstate 25. The north and south boundaries were chosen solely on the basis of the availability of data.

Piper diagrams of the water-quality data indicate that the water generally is a calcium bicarbonate or calcium sodium bicarbonate sulfate type (figs. 11 and 12). The distributions of points on the piper diagrams are similar, indicating that the data are not significantly different with respect to the major dissolved constituents. The mean composition of Rio Grande water at Isleta, which is approximately 12 miles south of Albuquerque, for September 1969 to August 1982 is similar in composition to ground water in the area (figs. 11 and 12). The mean specific conductance of ground water is 710 microsiemens per centimeter in the Geological Survey data set and 538 microsiemens per centimeter in the Environmental Improvement Division data set. The mean specific conductance of the Rio Grande water at Isleta for September 1969 to August 1982 is 463 microsiemens per centimeter, indicating the ground water generally has a larger specific conductance than water in the Rio Grande. 


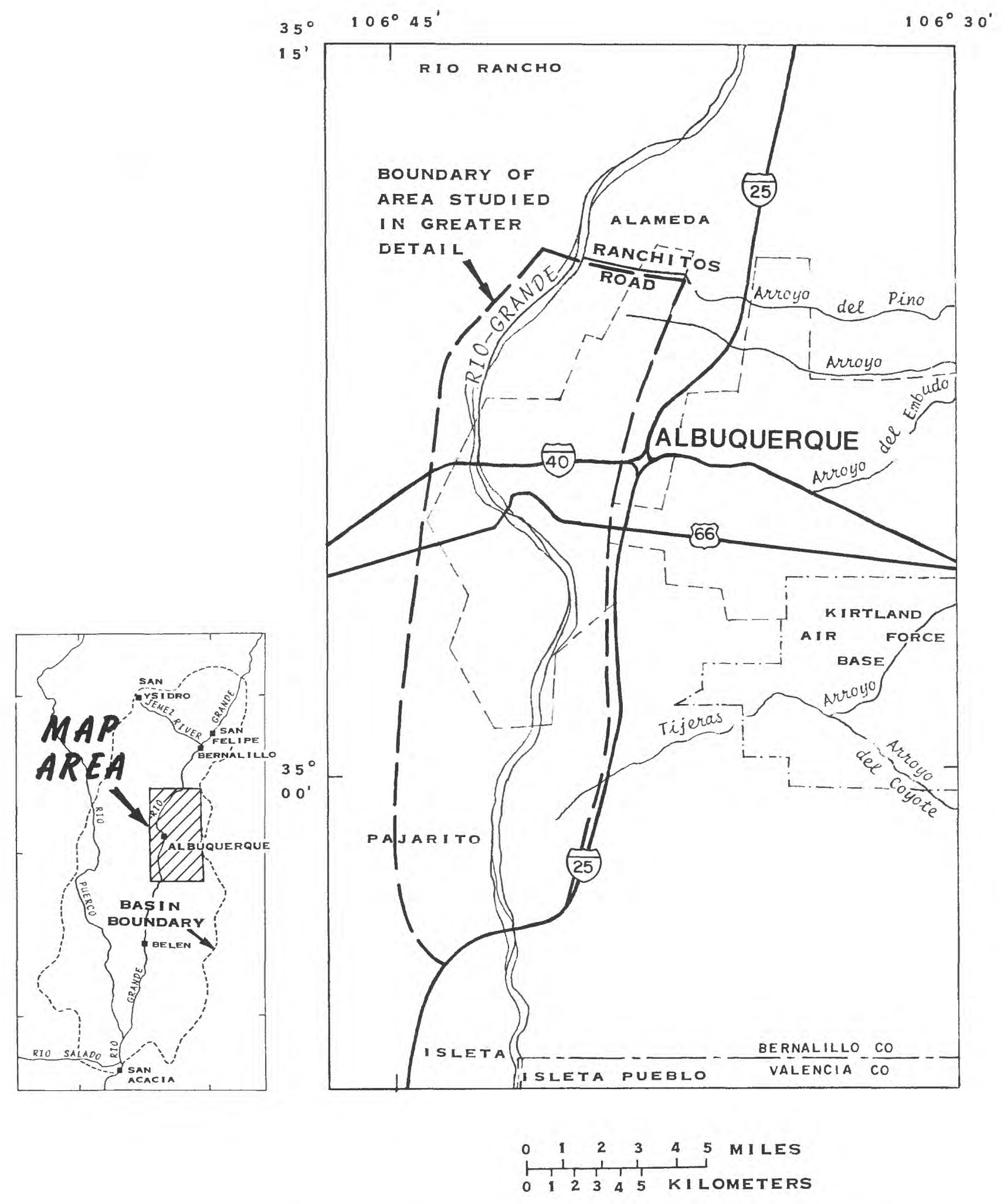

Figure 10.--Location of the Rio Grande valley near Albuquerque study area. 


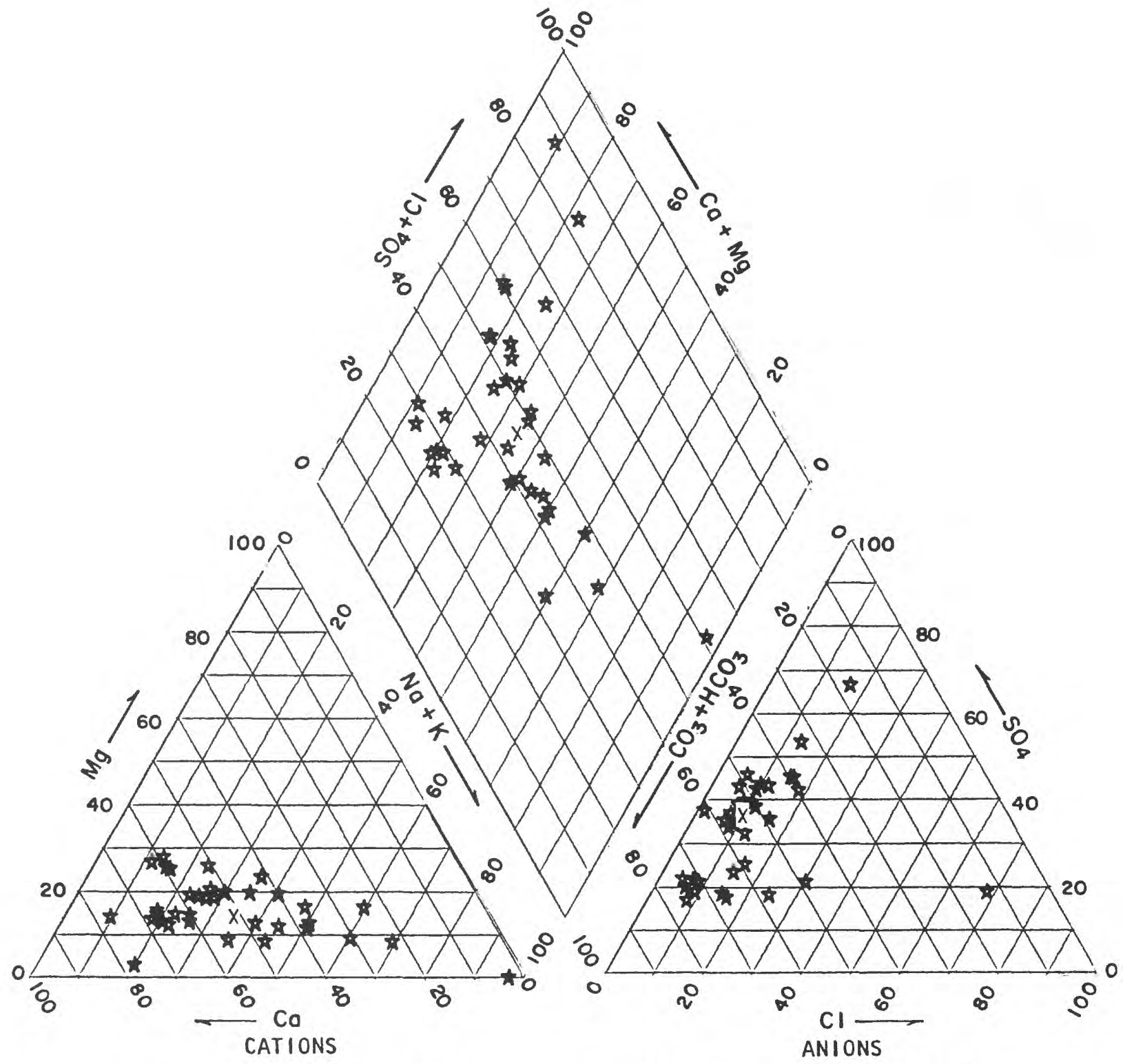

PERCENTAGE OF TOTAL IONS, IN MILLIEQUIVALENTS PER LITER

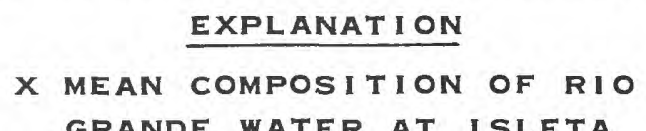

GRANDE WATER AT ISLETA

anAlysis

CATIONS

ANIONS

$\begin{array}{llll}\mathrm{Ca} & \text { Calcium } & \mathrm{Cl}_{1} & \text { Chloride } \\ \mathrm{Na} & \text { Sodium } & \mathrm{SO}_{4} & \text { Sulfate } \\ \mathrm{Mg} & \text { Magnesium } & \mathrm{CO}_{3} & \text { Carbonate } \\ \mathrm{K} & \text { Potassium } & \mathrm{HCO}_{3} & \text { Bicarbonate }\end{array}$

Figure 11.--Piper diagram of water-chemistry analyses in the U.S. Geological Survey data set. 


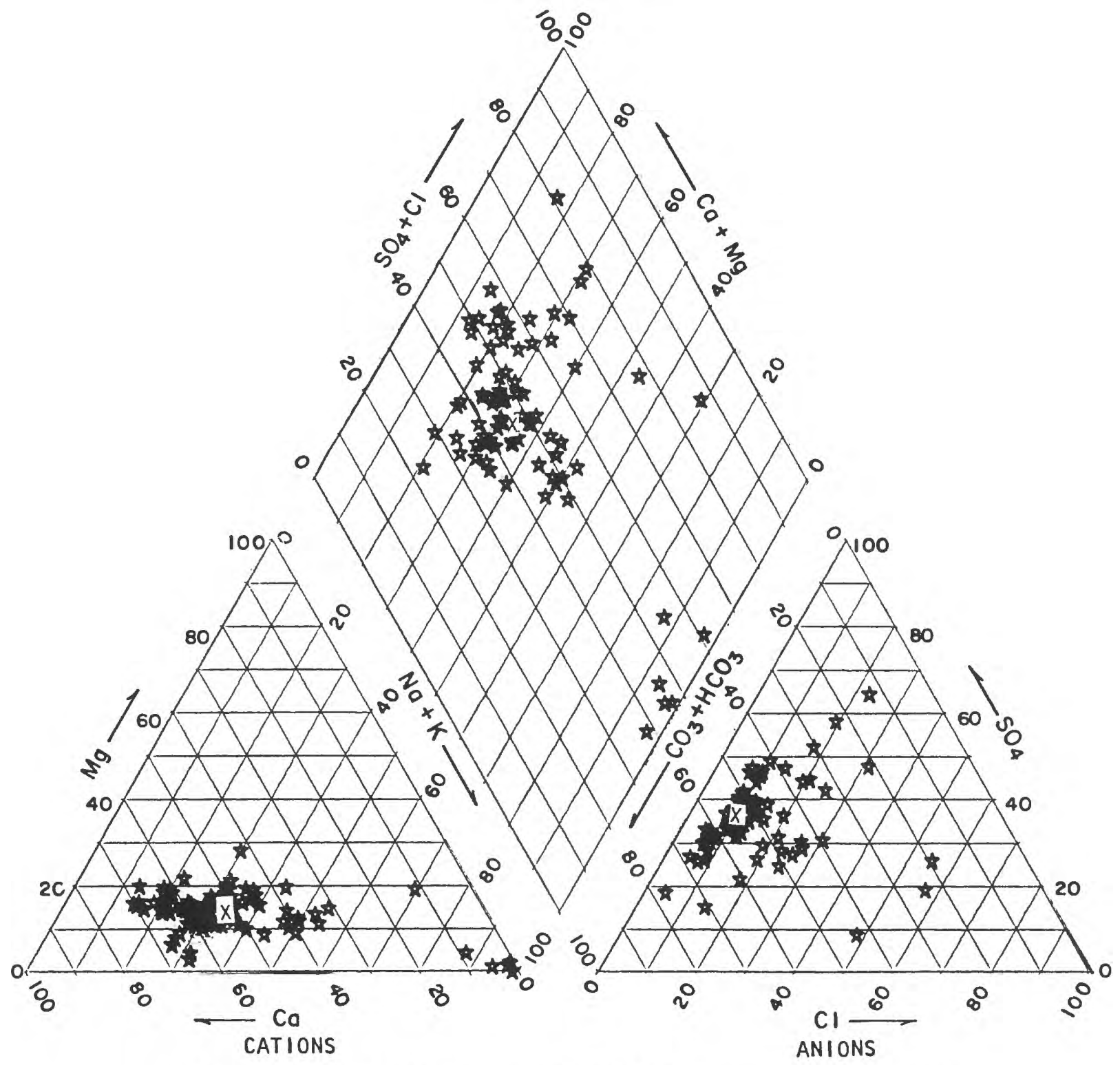

PERCENTAGE OF TOTAL IONS, IN MILLIEQUIVALENTS PER LITER

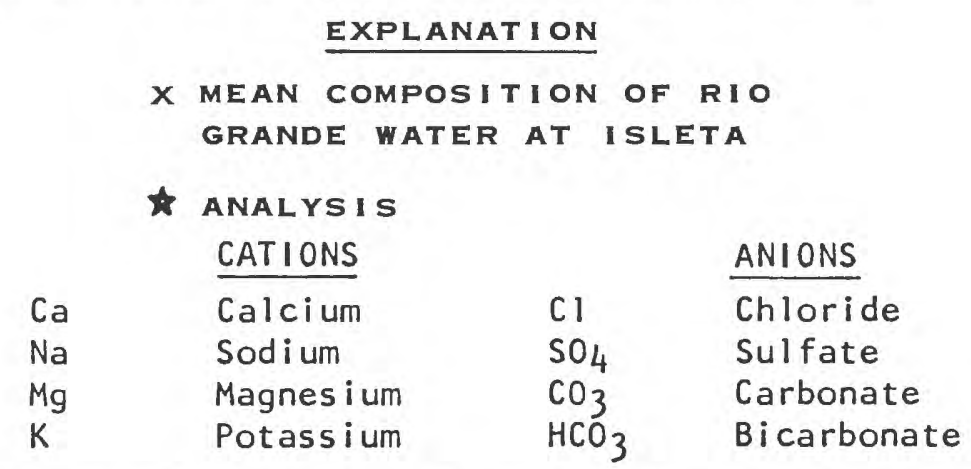

Figure 12.--Piper diagram of water-chemistry analyses in the Environmental Improvement Division data set. 
Spearman correlation analysis was performed on selected dissolved-ion concentrations to examine the relation among the dissolved constituents for both data sets. Spearman correlation coefficients were greater than 0.5 for iron and manganese, selenium and boron, arsenic and boron, and arsenic and nitrate for the data set (table 1). Only six analyses were used in the calculation of the correlation coefficients for boron and selenium and boron and arsenic, and only four analyses were used in the calculation for nitrate and arsenic. There was a -0.50270 correlation coefficient for iron and nitrate in the Survey data set. Spearman correlation coefficients were greater than 0.5 for selenium and manganese, selenium and iron, and selenium and zinc for the Environmental Improvement Division data set (table 1). In general, the correlation coefficients for the selected constituents were small, except for iron and manganese in the Survey data set. Thermodynamic constraints indicate that these two elements probably will correlate well because they both exist in soluble forms at a similar Eh (Hem, 1977). The differences in the correlation coefficients for specific ions in the two data sets may be the result of the different sampling and analytical procedures used.

Selected dissolved-ion concentrations have been plotted on the 1 and-use map in the Rio Grande valley near Albuquerque (p1.3). Iron concentrations greater than 200 micrograms per liter occur throughout the area. Arsenic concentrations greater than 10 micrograms per 1 iter occur in the central part of the area.

Nitrate (as nitrogen) concentrations generally are less than 1 milligram per liter throughout the area ( 1 1.3). The west-central part of the area has nitrate concentrations greater than 1.0 milligram per liter. Another small area in the southeastern part of the area has nitrate concentrations greater than 1.0 milligram per liter; one sample has 150 milligrams per liter of nitrate ( $p 1.3)$.

Ground-water contamination has been documented in several areas of the Rio Grande valley near Albuquerque (McQuillan, 1982 and 1984), and a U.S. Environmental Protection Agency contractor presently (1985) is studying organic contamination of ground water in the San Jose area (fig. 13, pl. 3). Classes of organic compounds detected in ground water include volatiles, acids, ethers, ketones, aliphatic hydrocarbons, and polycyclic compounds (McQuillan, 1982, p. 258). One municipal-supply well was removed from production because of the large concentrations of organic compounds in water from the well. McQuillan (1982, p. 359) suggested that multiple sources are responsible for this ground-water contamination.

The Environmental Improvement Division detected gasoline floating on ground water in several areas in the Rio Grande valley near Albuquerque (McQuillan, 1984). The Environmental Improvement Division is presently (1985) studying these areas and collecting other samples at areas where gasoline contamination is suspected. 


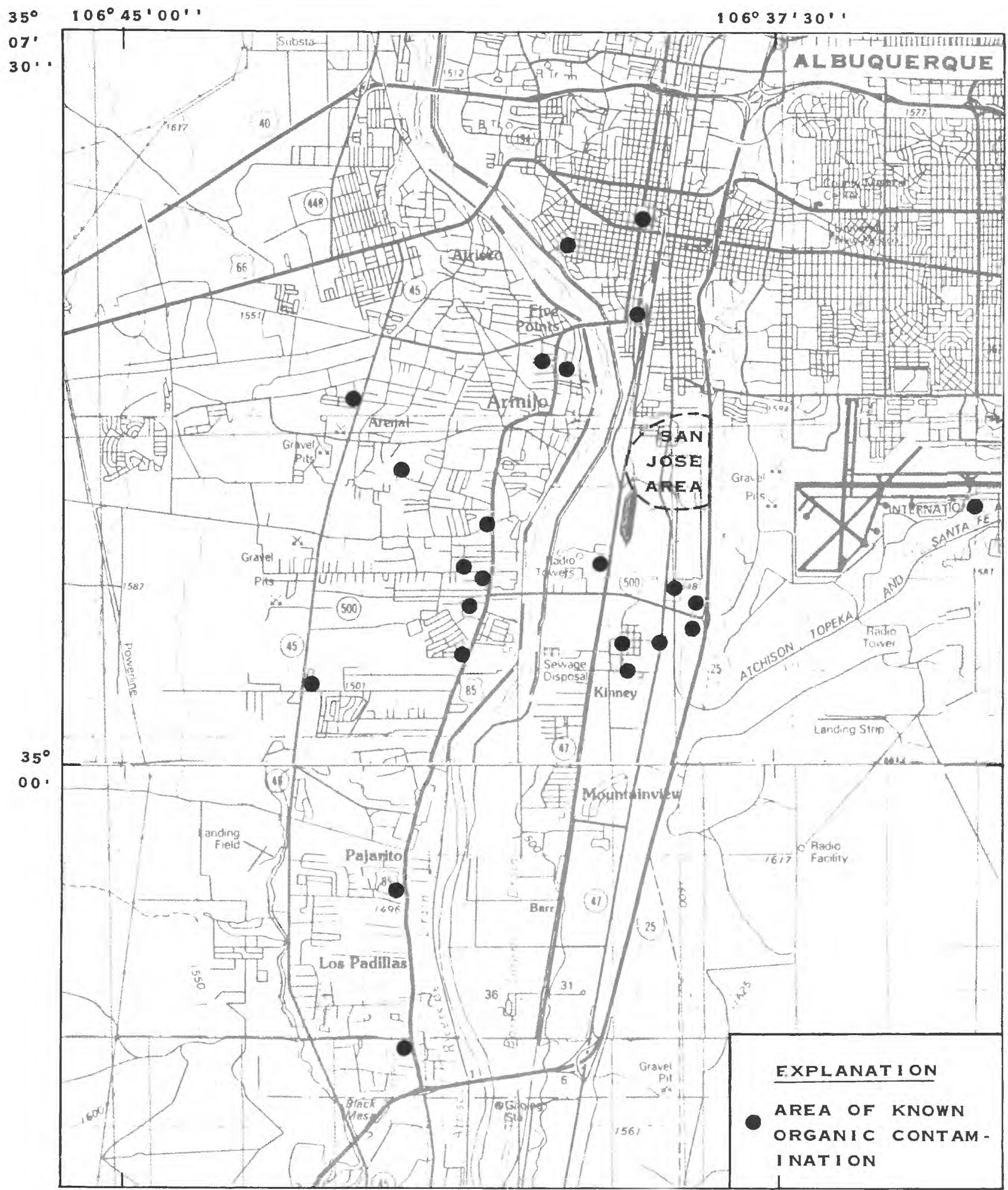

Base from U.S. Geological Survey

1:100,000 map series; Albuquerque

(1978) and Belen (1979)

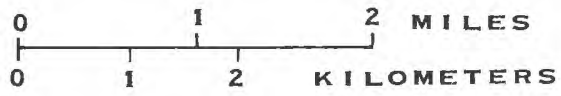

Figure 13.--Location of organic contamination of ground water in the Rio Grande valley near Albuquerque (modified from McQuillan, 1984). 
Table 1. Spearman correlation coefficients for selected dissolved constituents

[ Top number $=$ Speaman correlation coefficient;

bottom number $=$ number of analyses used in calculation]

\begin{tabular}{|c|c|c|c|c|c|c|c|}
\hline Constituent & Manganese & Iron & Boron & Zinc & Selenium & Nitrate & Arsenic \\
\hline Manganese & & $\begin{array}{c}0.82184 \\
24\end{array}$ & 2 & $\begin{array}{c}-0.02574 \\
23\end{array}$ & $\begin{array}{c}-0.49293 \\
23\end{array}$ & 0 & $\begin{array}{c}0.07501 \\
24\end{array}$ \\
\hline Iron & $\begin{array}{c}0.39763 \\
29\end{array}$ & & $\begin{array}{c}0.07785 \\
7\end{array}$ & $\begin{array}{c}0.08568 \\
27\end{array}$ & $\begin{array}{c}0.03260 \\
27\end{array}$ & $\begin{array}{c}-0.50270 \\
12\end{array}$ & $\begin{array}{c}-0.02014 \\
28\end{array}$ \\
\hline Boron & $\begin{array}{c}0.06303 \\
25\end{array}$ & $\begin{array}{c}0.00636 \\
24\end{array}$ & 松 & $\begin{array}{c}-0.17150 \\
O_{G \times} \quad 6\end{array}$ & $\begin{array}{c}0.95486 \\
6\end{array}$ & $\begin{array}{c}-0.36037 \\
7\end{array}$ & $\begin{array}{c}0.73529 \\
6\end{array}$ \\
\hline Zinc & $\begin{array}{c}-0.03880 \\
22\end{array}$ & $\begin{array}{c}0.31041 \\
19\end{array}$ & $\begin{array}{c}0.26209 \\
26\end{array}$ & Vर & $\begin{array}{r}0.25791 \\
27\end{array}$ & $\begin{array}{c}0.00000 \\
4\end{array}$ & $\begin{array}{c}-0.49167 \\
27\end{array}$ \\
\hline Selenium & $\begin{array}{c}0.57145 \\
9\end{array}$ & $\begin{array}{c}0.56365 \\
8\end{array}$ & $\begin{array}{c}0.21229 \\
13\end{array}$ & $\begin{array}{c}0.72123 \\
8\end{array}$ & T仿 & $\begin{array}{c}0.25820 \\
4\end{array}$ & $\begin{array}{c}0.07325 \\
27\end{array}$ \\
\hline Nitrate & $\begin{array}{c}-0.21687 \\
22\end{array}$ & $\begin{array}{c}-0.05809 \\
22\end{array}$ & $\begin{array}{c}0.41947 \\
32\end{array}$ & $\begin{array}{c}0.07522 \\
25\end{array}$ & $\begin{array}{c}0.33144 \\
18\end{array}$ & & $\begin{array}{c}0.94868 \\
4\end{array}$ \\
\hline Arsenic & $\begin{array}{c}0.08349 \\
19\end{array}$ & $\begin{array}{c}-0.27001 \\
14\end{array}$ & $\begin{array}{c}0.24285 \\
27\end{array}$ & $\begin{array}{c}-0.05676 \\
19\end{array}$ & $\begin{array}{c}0.20233 \\
19\end{array}$ & $\begin{array}{c}-0.02366 \\
32\end{array}$ & \\
\hline
\end{tabular}




\section{PRELIMINARY EVALUATION OF RELATION BETWEEN LAND USE AND GROUND-WATER CHEMISTRY}

Recharge to the ground-water system needs to coincide with a particular 1 and use for the ground-water chemistry to be affected by that 1 and use. In a large part of the Albuquerque-Belen basin, the depth to water is greater than 100 feet, and there is virtually no natural recharge. In these areas, there is not any natural mechanism for 1 and use to have an effect on ground-water chemistry. Unnatural recharge to the regional ground-water system as the result of leakage from storage tanks or infiltration from storage or waste pits possibly could affect ground-water chemistry in these areas, although large volumes of recharge and a significant amount of time would be necessary before ground-water chemistry is affected.

Ground water in areas corresponding to open-space 1 and use, which occupies a majority of the basin, also has a relatively low susceptibility to effects from land use. Livestock grazing is the major activity on land classified as open space and the density of livestock is low, so effects on ground-water chemistry from this 1 and use are expected to be minimal.

Human activities are expected to have a greater effect on ground-water chemistry in the Rio Grande valley on the basis of hydrologic and land-use factors. The depth to water generally is less than 30 feet in the Rio Grande valley. Recharge to the ground-water system occurs as the result of infiltration of excess applied irrigation water. Infiltration of effluent from onsite waste-disposal systems also could recharge the system. There is a variety of types of 1 and use in the Rio Grande valley, and many of the 1 and uses could have effects on ground-water chemistry.

Agricultural land use probably affects the ground-water chemistry in the Rio Grande valley because of the large amount of evapotranspiration that occurs. Assuming an irrigation efficiency of 50 percent and an average specific conductance of irrigation water of 463 microsiemens per centimeter, the specific conductance of excess applied irrigation water would be 926 microsiemens per centimeter. The specific conductance of this recharge and of ground water in the Rio Grande valley generally is larger than in areas adjacent to the valley (fig. 9). This difference may indicate that agricultural land use has affected ground-water chemistry. Although fertilizers and organic compounds used for weed and pest control also might be expected to affect ground-water chemistry in the valley, presently (1985) few or no organic-compound analyses exist in agricultural land-use areas to document this possibility.

Urbanization in the Rio Grande valley has resulted in a change in land use from agricultural to residential; the change in land use has resulted in a change in the chemical composition of recharge water. Recharge associated with agricultural land use is surface water that has had dissolved constituents concentrated by evaporation. This water is relatively oxidized or contains dissolved oxygen because the water is initially in equilibrium with oxygen in the atmosphere. In some areas in the valley, a municipal sewer system is not available or houses are not connected to the system. In these areas, residents have onsite waste-disposal systems. The major form of 
recharge associated with residential land use is infiltration of water from onsite waste-disposal systems. This recharge contains TOC, BOD, and COD. Loading of the ground-water system with significant TOC, BOD, and COD occurs in areas that have a relatively high density of onsite waste-disposal systems. The loadings of carbon and oxygen demand in the ground-water system could result in reducing conditions in the aquifer. Iron and manganese are relatively insoluble in oxidizing conditions, but are soluble in reducing conditions (Hem and Cropper, 1959). Furthermore, trace metals are adsorbed on iron and manganese oxides, and dissolution of these oxides can result in increases of dissolved trace-element concentrations (Suarez and Langmuir, 1976 ; and Hem, 1977).

The relatively large dissolved-iron concentrations in ground water in the Rio Grande valley near Albuquerque ( $p 1$. 3) could be the result of the change in land use from agricultural to residential. Iron in the aquifer or unsaturated zone is expected to be oxidized or relatively insoluble in agricultural areas because of infiltration of oxidized water. Iron is expected to be reduced or soluble in unsewered residential areas because of the inflow of septic-tank effluent. The degree to which ground water in an unsewered residential area is affected by septic-tank effluent depends on the quantity of effluent, composition of the effluent, length of time effluent has recharged the aquifer, mineralogy of the aquifer, flow rate in the aquifer, and density of septic tanks. The random distribution and considerable range of dissolved-iron and dissolved-manganese concentrations in the Rio Grande valley probably are due to the interaction of these factors. If the change in 1 and use has resulted in the large iron concentrations in the Rio Grande valley, the same process could be occurring throughout the Southwest alluvialbasins ground-water region because of the increasing urbanization that is occurring in the region.

Ground-water contamination as the result of industrial land use has been documented in the San Jose area in the Rio Grande valley near Albuquerque (fig. 13, p1. 3) (McQuillan, 1982). Other areas of organic contamination that coincide with industrial land use also may exist in the valley. Presently (1985) few organic analyses of ground water from the valley exist; the Environmental Improvement Division currently (1985) is collecting such data.

Institutional or commercial land use is not expected to affect groundwater chemistry with the possible exceptions of infiltration of storm runoff, infiltration of waste products from laundry facilities, or infiltration of gasoline from leaking storage tanks. Leaking storage tanks have been found in several areas of the Rio Grande valley near Albuquerque. In these areas, commercial 1 and use coincides with this contamination. 
In 1984, the U.S. Geological Survey began regional assessments of groundwater contamination in 14 areas, one of which was the Albuquerque-Belen basin. The purpose of this reconnaissance study is to provide information about hydrology, land use, ground-water chemistry, and the effects of land use on ground-water chemistry in the basin.

Ground-water recharge occurs along the basin margins. Ground water flows from the basin margins toward the basin axis and then southward. Ground-water discharge occurs as evapotranspiration in the Rio Grande valley, pumpage, and ground-water flow to the Socorro basin, the alluvial basin to the south.

Maps delineating land use were prepared for the entire basin and for the Rio Grande valley near Albuquerque. Open-space land use, which primarily is used for grazing livestock, occupies the majority of the basin. In the Rio Grande valley, agricultural and residential land uses are predominant; in the area near Albuquerque, the land also is used for commercial, institutional, and industrial purposes.

The Albuquerque-Belen basin was divided into seven zones on the basis of water chemistry. These water-chemistry zones indicate that large variations in water chemistry exist in the basin as the result of natural processes.

Ground water in the majority of the Albuquerque-Belen basin has a relatively low susceptibility to ground-water contamination on the basis of hydrologic and land-use factors. Ground water in the Rio Grande valley has a relatively high susceptibility to ground-water contamination.

Dissolved-iron concentrations in water in the Rio Grande valley near Albuquerque are greater than dissolved-iron concentrations in areas adjacent to the valley. These relatively large dissolved-iron concentrations may be due to the change from agricultural land use to residential land use. This change results in a change in the chemical composition of recharge to the ground-water system. Recharge associated with agricultural land use is relatively oxidized because the water is in equilibrium with the atmosphere. Recharge associated with residential land use (onsite waste-disposal effluent) is relatively reduced and contains organic carbon, biological oxygen demand, and chemical oxygen demand. The constituents in the onsite waste-disposal effluent cause reducing conditions in the aquifer and dissolution of iron and manganese oxides. Trace elements adsorbed to iron and manganese oxides could be remobilized in ground water after dissolution of the oxides. If the change in land use has caused the relatively large dissolved-iron concentrations, the process could be occurring in many areas of the southwestern United States. 


\section{SELECTED REFERENCES}

Albuquerque Municipal Development Department, 1985, Generalized land use, Albuquerque/Bernalillo County, January 1983: scale 1:96,000, 1 sheet.

Anderson, J.R., Hardy, E.E., Roach, J.T., and Witmer, R.E., 1976, A land use and land cover classification system for use with remote sensor data: U.S. Geological Survey Professional Paper 964, 28 p.

Back, William, 196l, Techniques for mapping of hydrochemical facies: U.S. Geological Survey Research no. 423, Exploration and Mapping Techniques, p. D380-D382.

Birch, F.S., 1982, Gravity models of the Albuquerque basin, Rio Grande rift, New Mexico: Geophysics, v. 47, no. 8, p. 1185-1197.

Bjorklund, L.J., and Maxwel1, B.W., 1961, Availability of ground water in the Albuquerque area, Bernalillo and Sandoval Counties, New Mexico: New Mexico State Engineer Technical Report 21, $117 \mathrm{p}$.

Bryan, Kirk, and McCann, F.T., 1937, The Ceja del Rio Puerco; a border feature of the Basin and Range Province in New Mexico, Part I, Stratigraphy and structure: Journal of Geology, v. XIV, no. 8, p. 801-828.

Craigg, S.D., 1984, Hydrologic data on the Pueblos of Jemez, Zia, and Santa Ana, Sandoval County, New Mexico: U.S. Geological Survey Open-File Report $84-460,37 \mathrm{p}$.

Freeze, R.A., and Cherry, J.A., 1979, Groundwater: Englewood C1 iffs, New Jersey, Prentice-Ha11, Inc., 604 p.

Gabin, V.L., and Lesperance, L.E., 1977, New Mexico climatological data Precipitation, temperature, evaporation, and wind, monthly and annual means, 1850-1975: Socorro, New Mexico, W.K. Summers and Associates, $436 \mathrm{p}$.

Galusha, Ted, 1966, The Zia Sand Formation, new early to medial Miocene beds in New Mexico: American Museum Novitates, no. 2271, 11 p.

Hawley, J.W., 1978, Guidebook to the lower Rio Grande rift in New Mexico and Colorado: New Mexico Bureau of Mines and Minerals Resources Circular 163, $241 \mathrm{p}$.

Heath, R.C., 1984, Ground-water regions of the United States: U.S. Geological Survey Water-Supply Paper 2242, 78 p.

Helsel, D.R., and Ragone, S.E., 1984, Evaluation of regional ground-water quality in relation to 1 and use, U.S. Geological Survey Toxic-Waste-Ground-Water Contamination Program: U.S. Geological Survey WaterResources Investigations Report 84-4217, 33 p. 


\section{SELECTED REFERENCES - Continued}

Hem, J.D., 1977, Reactions of metal ions at surfaces of hydrous iron oxide: Geochimica et Cosmochimica Acta, v. 41, p. 527-538.

Hem, J.D., and Cropper, W.H., 1959, Survey of ferrous-ferric chemical equilibria and redox potentials: U.S. Geological Survey Water-Supply Paper 1459-A, $31 \mathrm{p}$.

Kelley, V.C., 1977, Geology of the Albuquerque Basin, New Mexico: New Mexico Bureau of Mines and Mineral Resources Memoir 33, $59 \mathrm{p}$.

Kelly, T.E., 1982, History of water use in the greater Albuquerque area, in Grambling, J.A., Wells, S.G., and Callender, J.F., eds., Guidebook to Albuquerque country II: New Mexico Geological Society, 33rd Field Conference, p. 351-355.

Kernodle, J.M., and Scott, W.B., 1986, Three-dimensional model simulation of steady-state ground-water flow in the Albuquerque-Belen Basin, New Mexico: U.S. Geological Survey Water-Resources Investigations Report 84$4353,58 \mathrm{p}$.

Lambert, P.W., 1968, Quaternary stratigraphy of the Albuquerque area, New Mexico: Albuquerque, University of New Mexico, unpublished Ph.D. dissertation, 329 p.

McQuillan, Dennis, 1982, Pollution of the Rio Grande valley-fill aquifer, in Grambling, J.A., Wells, S.G., and Callender, J.F., eds., Guidebook to Albuquerque country II: New Mexico Geological Society, 33 rd Field Conference, p. 357-360.

1984, Water quality concerns in the Albuquerque South Valley, February 1984: Santa Fe, New Mexico Health and Environment Department, 18 p.

Metcalf and Eddy, Inc., 1972, Wastewater engineering, treatment, disposal and reuse: New York, McGraw-Hill, 782 p.

Middle Rio Grande Council of Governments of New Mexico, 1978, Alternative Iand use patterns for the middle Rio Grande area, water quality management plan: Albuquerque, $46 \mathrm{p}$.

Piper, A.M., 1944, A graphic procedure in the geochemical interpretation of water analyses: American Geophysical Union Transactions, v. 25, p. 914923 .

Suarez, D.L., and Langmuir, Donald, 1976, Heavy metal relationships in a Pennsylvania soil: Geochimica et Cosmochimica Acta, v. 40, p. 589-598. 


\section{SELECTED REFERENCES - Concluded}

Theis, C.V., 1938, Ground water in the middle Rio Grande valley, in (U.S.) National Resources Committee, Regional Planning, Part VI--Rio Grande Joint Investigation in the upper Rio Grande basin in Colorado, New Mexico and Texas, 1936-37: Washington, U.S. Government Printing Office, v. 1, pt. 2, p. 268-291.

Thomson, B.M., 1983, Groundwater contamination by nitrate in Albuquerque, New Mexico: Albuquerque, University of New Mexico, Bureau of Engineering Research Report CE83-1, 31 p.

Titus, F.B., 1961, Ground-water geology of the Rio Grande trough in northcentral New Mexico, with sections on the Jemez caldera and the Lucero uplift, in Northrop, S.A., Albuquerque country: New Mexico Geological Society, 12th Field Conference, p. 186-192.

U.S. Army Corps of Engineers, 1979, Albuquerque greater urban area water supply study, Appendix III: Albuquerque District, Hydrologic Engineering Center, various pagination.

U.S. Department of Commerce, 1965, Standard 1 and use coding manual; a standard system for identifying and coding land use activities: Washington, D.C., Urban Renewal Administration, Housing and Home Finance Agency and Bureau of Public Roads, $111 \mathrm{p}$.

Wright, H.E., Jr., 1946, Tertiary and Quaternary geology of the lower Rio Puerco area, New Mexico: Geological Society of America Bulletin, v. 57, p. 383-456. 